\title{
Promoting Forest Conservation through Ecotourism Income?
}

A case study from the Ecuadorian Amazon region

Sven Wunder

CENTER FOR INTERNATIONAL FORESTRY RESEARCH

Office address: Jalan CIFOR, Situ Gede, Sindangbarang, Bogor 16680, Indonesia Mailing address: P.O. Box 6596 JKPWB, Jakarta 10065, Indonesia

Tel.: +62 (251) 622622; Fax: +62 (251) 622100

E-mail: cifor@cgiar.org

Website: http://www.cgiar.org/cifor 


\section{Contents}

Summary 1

Tourism, Economics and Conservation 1

The Study Area: Cuyabeno Wildlife Reserve, Ecuador 3

The Quichuas: A Salary Model 5

The Cofans of Zábalo: An Autonomous Model 6

The Siona-Secoyas: An Intermediate Model 9

A Comparison of Local Tourism Income 11

$\begin{array}{ll}\text { Socioeconomic Impacts } & 13\end{array}$

Environmental Impacts $\quad 14$

$\begin{array}{ll}\text { Conclusions and Recommendations } & 17\end{array}$

$\begin{array}{ll}\text { Endnotes } & 19\end{array}$

$\begin{array}{ll}\text { Literature Cited } & 23\end{array}$ 


\section{Figure}

Figure 1. From tourism participation to conservation

\section{Map}

Map 1. Cuyabeno Wildlife Reserve

\section{Tables}

Table 1. Mutual obligations of Transturi and the Zancudo community according to 1994 Letter of Agreement (LoA)

Table 2. Zancudo tourism income

Table 3. Playas de Cuyabeno tourism income 7

Table 4. Zábalo yearly tourism income 8

Table 5. San Pablo tourism income 10

Table 6. Puerto Bolívar yearly tourism income, from collaboration with Nuevo Mundo and Neotropic agencies

Table 7. Comparing local tourism income in Cuyabeno villages

Table 8. Examples of potential conflicts between the goals of raising local tourism income and of minimising social and environmental impacts 


\section{List of Acronyms}

BMZ Bundesministerium für wirtschaftliche Zusammenarbeit und Entwicklung (Federal German Ministry for Economic Cooperation and Development)

CDR Centre for Development Research (Denmark)

CIFOR Center for International Forestry Research

GTZ Deutsche Gesellschaft für Technische Zusammenarbeit (German Technical Cooperation)

ha hectares

ICDP Integrated Conservation and Development Project

INEFAN Instituto Ecuatoriano Forestal y de Areas Naturales y Vida Silvestre (Ecuadorean Institute for Forestry, Natural Areas and Wildlife)

IUCN The World Conservation Union

LAC Limits of Acceptable Change

LoA Letter of Agreement

MAG Ministerio de Agricultura y Ganadería (Ministry of Agriculture and Livestock)

masl metres above sea level

NGO Non-governmental organisation

NTFP Non-timber forest product

PROBONA Programa de Bosques Nativos Andinos (Programme for Native Andean Forests)

PROFORS Programa Forestal de Sucumbíos (Forest Programme for Sucumbíos Region)

TCM Travel Cost Method (of economic valuation)

US\$ United States dollar

Yr year 


\title{
PROMOTING FOREST CONSERVATION THROUGH ECOTOURISM INCOME?
}

\author{
A case study from the Ecuadorian Amazon region
}

\author{
Sven Wunder
}

\begin{abstract}
Summary
A principal criterion for classifying a tourism operation as 'ecotourism' is that local residents at the site should receive substantial economic benefits, which serve both to raise local living standards and as enhanced incentives for nature conservation. This paper sets out a methodological framework for analysis of the alleged participationincome-conservation link, and applies it to the Cuyabeno Wildlife Reserve in the Ecuadorian Amazon region. Three Cuyabeno ethnic groups involved in tourism, the Quichuas, Siona-Secoyas and Cofans, are characterised by different tourism participation models, ranging from autonomous operations to pure salary employment. Results do not support the frequently held belief that autonomous operations are 'better off' by yielding higher local benefits; rather, income size is determined by the site-specific degree of tourism specialisation, which largely depends on the tourist appeal and level of conservation of the natural site. Annual tourism cash flows are found to be much higher than previously estimated (from US\$15 000-50 000 per village), which represents a significant rise in local purchasing power. In terms of conservation incentives, this study confirmed that income from tourism tends to change local attitudes and behaviour, such as reducing overexploitation, creating 'untouchable' zones and user quotas. The more autonomous the operation, the more incentive exists to rationalise resource use. Also, the mere fact that labour time is invested in tourism leaves less opportunity for hunting and other activities that may have been practised unsustainably in the past. Further, tourism income helps to protect the Cuyabeno Reserve against important external threats, such as oil drilling and squatter colonisation. Recommendations include proposals for gradually augmenting local participation, strengthening both incentives and tourist operations in the fields of food production, handicrafts and the training of local tourist guides. Even with these safeguards, the nexus of social-economic-environmental change will often come in clusters that make it impossible to distinguish between 'desirable' and 'undesirable' impacts, in the unambiguous manner suggested by the axioms of ecotourism.
\end{abstract}

\section{TOURISM, ECONOMICS AND CONSERVATION ${ }^{1}$}

Tourism is one of the sectors that globally has faced the fastest economic growth rates throughout the last decade. Furthermore, for many developing countries, it has become a prime source of foreign exchange inflows. At the same time, tourism has a generally low negative impact on the environment compared to other productive sectors such as agriculture, cattle ranching and mining. With growing global pressures on forest resources and the search for models of sustainable development and sustainable forest use, it has thus been natural to look towards tourism in forest areas as a potential 'win-win' component in the design of conservation strategies and practices.

Tourism directed towards natural forests can be viewed as another element within the array of 'non-timber forest benefits', complemented by other forest services, such as watershed protection, carbon storage and erosion control, and by the exploitation of various non-timber forest products (NTFPs). As an, in principle, nonconsumptive use of the forest, it is a potentially wellsuited element for conservation. Moreover, the tourist appeal of a natural site (and hence its income-generating potential) tends to be closely related to its conservation level. Finally, unlike other forest services that are often valued too late, i.e., when forest loss has already led to visible environmental costs, nature tourism is able to produce 'in time' new and additional financial resources. These resources may provide important conservation incentives for the relevant natural resource managers, by increasing the gains from conservation-based options, compared to competing, non-sustainable land uses (forest degradation and/or conversion).

In addition, tourism directed towards conservation areas also has an educational potential for the participant who, according to the ideology of ecotourism, may be enlightened and encouraged by his visit to generally support nature conservation. ${ }^{2}$

In the rapidly growing literature on this subject, considerable attention has been given to adequately defining 'ecotourism' - a model of nature-oriented

\footnotetext{
*Economist, PhD, Centre for Development Research, Gammel Kongevej 5, DK-1610 Copenhagen V, Denmark, and Instituto de Pesquisa Econômica Aplicada (IPEA), Rio de Janeiro, Brazil. E-mail: sven@ipea.gov.br
} 
tourism that combines the above features of sustainable development and environmental consciousness building. Particular (and perhaps sometimes excessive) focus has been on determining tourism's environmental impacts; in strategic terms, tourism impacts should rather be evaluated relative to the environmental impacts of other ongoing activities. ${ }^{3}$ To summarise the general definitions used by different authors, ${ }^{4}$ three main rules may describe the conditions for using the label of ecotourism:

- minimising physical and social impacts on the visited area;

- provision of ecological education to the tourist ; and

- securing significant economic participation by local resource managers.

Obviously, in an age where a 'green image' and ecolabelling appeal to developed-country tourists, many operators have (ab)used the ecotourism label without complying with (any of) these three criteria. ${ }^{5}$ Moreover, one may ask at what level of precision these rules may be put into operation, and if they are fully consistent internally (see Conclusions and Recommendations).

Without entering into the sometimes fundamentalist discussion of what deserves to be called ecotourism and what does not, the following discussion will be limited only to the third pillar of ecotourism: the question of local economic participation. Does local participation produce a significant stream of income, in particular compared to traditional cash sources? And, if so, how does this affect residents' attitudes towards conservation and their resource management decisions?

In quantifying local tourism income, the different modes of cooperation between tourist operators and local communities in the study areas will be compared, ranging from residents employed on a wage basis by agencies to local autonomy in tourism operation. This will enable us to analyse correlations between modes of participation and the degree of benefit sharing.

Among NGOs and tourism analysts, it is often believed that local communities are economically better off by operating their own autonomous operation, although it is normally acknowledged that this requires certain skills and entrepreneurial spirit. In comparison, their weak bargaining position and marginalisation in a salary relationship with external operators would tend to maintain them in dependency and unequal benefit sharing where agencies reap the bulk of profits. This can be rephrased as the following working hypothesis:

Hypothesis 1: A higher degree of local autonomy in tourism operation triggers the generation of larger local income.
Within the framework of natural resource management, a more active participation and the higher local income from tourism would be expected to augment the tourismled incentive for conservation. Potentially, three different pathways of causality could be at work, linking socioeconomic changes to altered conservation attitudes and behaviour among different (groups of) resident households.

First, local livelihood dependence on activities that degrade the environment (agriculture, timber exploitation, cattle ranching, etc.) would be reduced, i.e., a tourism income effect. Secondly, local environmental awareness may be increased because of locally conceived explicit trade-offs between tourism and other activities, leading to a more resource-efficient day-today management and a substitution of activities that directly jeopardise the tourism operation, i.e., a tourism substitution effect. Thirdly, tourism and its derived income may also constitute a means of strengthening local communities in the struggle against external agents that may be seeking access to exploit natural resources in an unsustainable manner (loggers, in-migrant squatters, mining companies, etc.), i.e., a local empowerment effect.

On aggregate, local income generation from tourism is thus expected to produce a composite 'substitution effect' in the productive sphere that alleviates pressures of ongoing (or expected future) natural resource degradation. The alleged positive link between tourism income and conservation can be formulated as a second hypothesis for our case study:

Hypothesis 2: Higher local tourism income provides an efficient incentive for changed conservation attitudes and behaviour, by reducing both local resource pressures and potential external environmental threats.

The conceptual premises in the expected stage-wise link from tourism participation to conservation can be graphically represented (Figure 1). The mode of participation is supposed to influence the extent of local income generation (Hypothesis 1). In turn, additional income and the derived socioeconomic changes ${ }^{6}$ will influence conservation levels along three different causal lines (Hypothesis 2).

Whereas the ecotourism literature has dealt quite extensively with the environmental impacts of tourism (e.g., Stankey et al. 1985; Ziffer 1989; Whelan 1991; Boo 1992), the economic dimension has generally received less attention. When economic aspects are treated, this has been done mostly in rather general and 
Figure 1. From tourism participation to conservation (Making explicit the main premises)

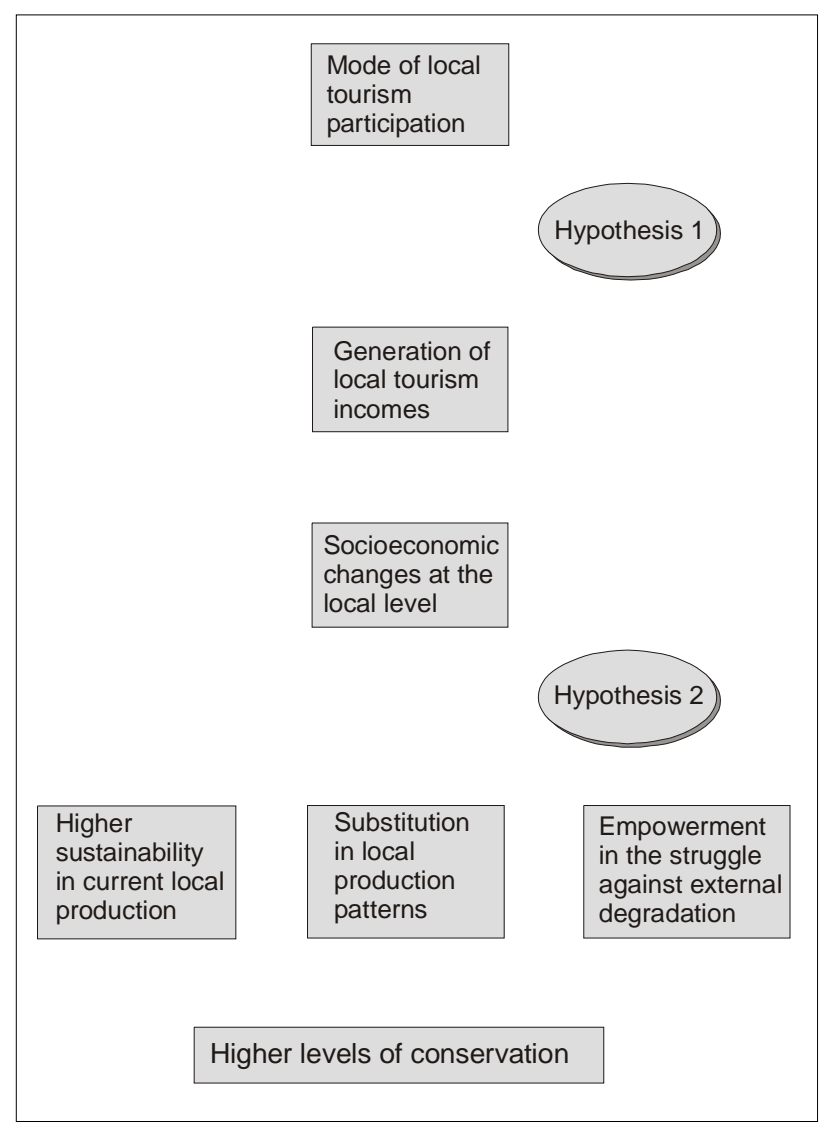

unquantified terms (e.g., Healy 1988, 1992; Laarman and Durst 1991). On the other hand, some quantifications, such as in Tobias and Mendelsohn (1991), employ the travel cost method that aims to measure a more abstract social value, rather than the actual cash flows that are decisive for the determination of conservation incentives. $^{7}$

Some analysis of ecotourism cash flows is provided by Groom et al. (1991) for the Madre de Dios region in Peru. It is found that tourism benefit generation and distribution is quite distinct based on the zone of destination; the 'backpacker' area of Puerto Maldonado, with easy access and a more disturbed natural environment, generates ten times less yearly income (US\$ 172 000) than the virgin but remote Manu Biosphere rainforest reserve (US\$ 1700 000) that caters to upmarket tourists. However, in terms of local income generation, this difference is partially offset by the higher local share $(25 \%)$ in the former tourist expenditure, as compared to $11 \%$, so that gross local tourism income amounts to US\$ 42 910/yr in Puerto Maldonado and US\$ 192 695/yr in Manu. ${ }^{8}$

Drumm (1991) obtains similar results for the Ecuadorian Amazon region. In spite of significantly higher aggregate tourism spending in the exclusive and pristine lower Napo region (US\$ $3860000 / y r$ ) than in the cheaper and progressively degraded upper Napo (US\$ 1 $340000 / \mathrm{yr}$ ), local income is higher in the latter case (US\$ $357000 / y r)$ compared to the former $(339,000 \mathrm{US} \$ / \mathrm{yr})$. Apparently, this is due to the luxury-type of spending by upmarket tourists relying more on goods imported from outside the region, whereas the backpacker-type of demand can easier be satisfied by production factors of local origin (food, guides, transport, etc.). ${ }^{9}$

Finally, a comprehensive study of ecotourism in Belize by Lindberg and Enriquez (1994) underlines that, in all of the investigated sites, local communities profited significantly from tourism directed towards adjacent protected areas, by selling handicrafts, providing accommodation and other services. ${ }^{10}$ Other than local inflation effects, created by the tourism-derived competitive demand for local resources (rising prices for labour, food, land), the site-specific economic, social and environmental impacts were generally positive. On aggregate, the results of the authors' quantitative interviews confirm clearly that tourism has increased the local communities' support to Belize's system of protected areas.

\section{THE STUDY AREA: CUYABENO WILDLIFE RESERVE, ECUADOR}

As a case study of local economic participation in tourism, the Cuyabeno Reserve in the north of Ecuador's Amazon region (see Map 1) exhibits several advantages. First, the creation of the Reserve within its present boundaries was heavily influenced by the emerging tourism boom in the area, as part of the struggle against other land use interests (oil exploration, squatters, African palm plantations). Secondly, the different indigenous groups that live inside the Reserve have developed different modes of tourism participation, which allows for a comparative analysis. Finally, in historical terms, tourism development in Cuyabeno has occurred largely as a result of private sector 'laissez faire' initiatives, not within a framework of donor-driven integrated conservation and development projects (ICDPs). ${ }^{11}$ Considerable financial subsidies and technical assistance that tend to be inherent in ICDPs may have beneficial impacts on resource use patterns, but they may also lead to biased results in the analysis of economic sustainability.

The Cuyabeno Wildlife Reserve was created in 1979 as a response by the Ecuadorian State to protect a biodiversity-rich area in the northeast, bordering Colombia and Peru, against a growing pressure of spontaneous colonisation that followed in the aftermath 
Map 1. Cuyabeno Wildlife Reserve

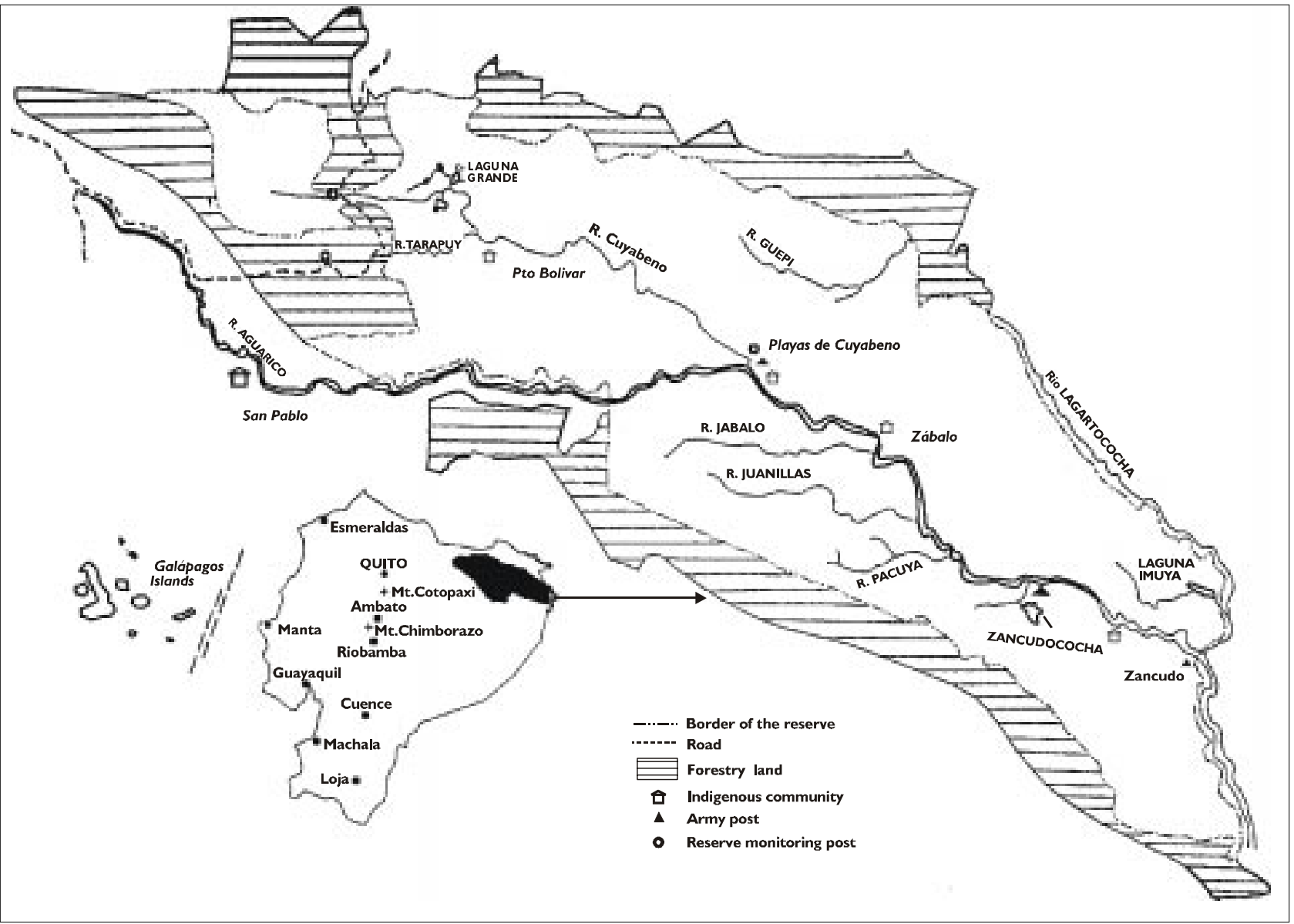

of oil companies' exploration and drilling activities. Oil exports from the Amazon have accounted for up to 50\% of Ecuador's foreign exchange earnings during recent decades, a figure, which is impossible to match by ecotourism and other sustainable use incomes. ${ }^{12}$ Clearly, this basic macroeconomic reality constitutes a direct external pressure on the Amazon region which is harder to challenge than the derived colonisation pressure along oil companies' penetration roads. ${ }^{13}$ Clashes between environmentalists on the one hand and foreign oil companies and related national economic interests on the other have thus been a recurrent theme on the national environmental agenda.

As a consequence, it is not surprising that the state agency for forestry, wildlife and natural areas, INEFAN, and its corresponding institutional predecessors, have been rather weak guardians of the Cuyabeno Reserve. The understaffed park rangers have been unable to prevent systematic encroachment in the western part of the park. As a realistic response, in 1994 about 50000 ha of the original reserve area was excluded.

Nevertheless, the original land area of the Reserve was more than doubled in 1991 by including a zone of 400
000 ha to the west. Tourism interests played a significant part in lobbying for that decision. Since 1985, pioneer Quito-based agencies such as Nuevo Mundo, and later Etnotur and Neotropic, had initiated successful operations in the Cuyabeno lakes. In 1991, the agency Transturi, one of the important actors in the tourism sector, decided to move its 48-passenger floating river hotel ('Flotel Orellana') from the area of Limoncocha ${ }^{14}$ to the Aguarico river, which is southwest of the Cuyabeno lakes, i.e., without overlapping the area of the already established agencies. This move dramatically increased the number of visitors to the Cuyabeno area, from 970 in 1990 to 4879 in 1991, 3412 of which were Flotel guests (BMZa 1995: 289).

Transturi thus had a clear interest in enlarging the Reserve, hoping to protect their investments (in advertising, camp and infrastructure construction) and to prevent the type of degradation that had forced them out of Limoncocha. Committed to the principle of ecotourism, they also agreed to finance the new management plan for the Reserve, signed Letters of Agreement with Cuyabeno indigenous communities and implemented an environmental impact study of the Flotel operation (Ulloa 1994). 
Although many observers are worried about 'crowding effects' of uncontrolled tourism, especially in the Cuyabeno lakes, the aggregate entrance figures reveal that the number of visitors has stagnated since 1994. In 1995, an outright fall was registered, mainly because of the war between Ecuador and closely bordering Peru. In particular, Transturi has faced financial crisis, being unable to maintain its initially high visitor figures. This may in part be attributed to the growing competition by small agencies operating in and around the Cuyabeno lakes - some of them without due environmental concern, and INEFAN proving unable to enforce acceptable standards. Additionally, various indigenous groups aim to set up their own tourism operations on a small scale, supported by the PROFORS project and the NGO Fundación Natura. For the time being, there may thus be a saturation of tourist infrastructure in Cuyabeno, given the levelling-off in demand.

Various ethnic groups maintain settlements inside the Cuyabeno Wildlife Reserve, ${ }^{15}$ including the indigenous Sionas, Secoyas, Quichuas, Shuar and Cofans. Not all of them are 'natives' of the Reserve, in the sense that, for instance, Quichuas and Shuars have migrated to this area from other parts of the Amazon region within the last two decades. There are also significant differences in their productive models: for example, the Cofans maintain their original emphasis on hunting and gathering, whereas the Quichuas in Playas de Cuyabeno have gone into cattle ranching and agriculture, and are thus closer to the model practised by mestizo squatters. Obviously, this creates different degrees and types of resource pressures, e.g., in terms of deforestation vs overhunting.

Most of the indigenous groups that live inside the Reserve have to some extent been integrated into tourism operations, ${ }^{16}$ but hitherto, the local economic impact of this participation has only been estimated in a rudimentary manner. ${ }^{17}$ The field data that are presented in this paper have been gathered through: semistructured interviews in Cuyabeno villages, using a rapid appraisal of the socioeconomic framework and local tourism participation; $;{ }^{18}$ in situ observation of the tourism operation and a questionnaire designed for tourists; ${ }^{19}$ and questions of tourism employees and field managers. These were complemented by interviews, mainly of tour operators and other stakeholders based in Quito.

In this paper, we will first describe each of the modes of tourism participation, quantify the local benefits and compare the models. In the quantification, we will be interested in current income (rather than past benefits) and in the net returns to local production factors (i.e., deducting costs of gasoline, imported food, etc.). This will allow for a comparison of the local development impact that tourism demand is generating. The economic to the socioeconomic impacts of tourism, including social and distributional impacts. The environmental impacts that local tourism income in Cuyabeno are likely to have had are then examined. Finally the main results are presented and some recommendations made for tourism operators in Cuyabeno. The consistency of ecotourism criteria is assessed in the light of the Cuyabeno experience.

\section{THE QUICHUAS: A SALARY MODEL}

The Quichuas migrated to the Cuyabeno area during the last two decades. The two Quichua settlements of Playas de Cuyabeno (at the confluence of the Aguarico and Cuyabeno rivers) and Zancudo (near the Peruvian border) are characterised by their different geographical positions. Playas has much better access to the urban market of Lago Agrio, and practises a mixed economy; maize as the basic food crop, occasional wage labour in the tourist and petrol industries, sale of cash crops (maize, coffee, cocoa), occasional timber extraction and cattle raising.. Some cattle ranchers even dispose of around 40 head, so cattle expansion is in fact a prominent local deforestation motive. The number of households has increased from 15 to 52 during the last 10 years, which places an additional stress on land use.

Zancudo is located $70 \mathrm{~km}$ downriver, in a much more isolated position, where market orientation is rendered uneconomic by the high costs of transport. Consequently, Zancudo basically produces only maize and plantains for own-consumption, whereas hunting is the main source of protein. With only 10 families and a tendency for out-migration, its dynamics are clearly different from those of Playas.

People from both Playas and Zancudo are employed in the Transturi Flotel operation as cooks, boatmen, assistants, etc., on a permanent as well as on a day-labour basis. The remote community of Zancudo lies in the heart of the Transturi operation zone of mostly pristine rainforest, and it was thus essential for the company to secure an exclusive access and to gain stable local support. For this reason, a Letter of Agreement (LoA) between the two parties was signed in 1994 (see Table 1). Transturi delivers a number of goods and services, and the people of Zancudo act as guardians of the area. In particular, the monthly delivery of a cow (sic.) and other foodstuffs ${ }^{20}$ was thought to compensate the restriction in hunting that the Zancudo residents would have to accept in the tourism zone.

During two years of operation, it has become clear that the LoA is built on shaky ground. The hunting 
Table 1. Mutual obligations of Transturi and the Zancudo community according to 1994 Letter of Agreement (LoA)

\begin{tabular}{lc}
\hline Transturi obligations & Zancudo obligations \\
\hline $\begin{array}{l}\text { Provide local employment } \\
\text { Grant one head of cattle per } \\
\text { month }\end{array}$ & $\begin{array}{c}\text { Protect natural resources } \\
\text { against } \\
\text { External intruders }\end{array}$ \\
$\begin{array}{l}\text { Grant different food items } \\
\text { Offer medical services }\end{array}$ & $\begin{array}{c}\text { Abstain from hunting and } \\
\text { other degrading activities } \\
\text { in the area of tourism }\end{array}$ \\
Offer occasional air transport & operation \\
Provide school uniforms, etc. & tourism operation and \\
Pay school teacher salary & provide access to the area \\
Offer local education courses & \\
\hline
\end{tabular}

Source: Own elaboration based on Cemecotur/Transturi (1994)

restrictions - the main sacrifice on behalf of the Zancudo - are difficult to monitor for Transturi, and are thus not effective, given that the locals lack a clear incentive for complying with the scheme. On the Transturi side, employment is now much lower than during the construction of the tourist camps, especially with the slump in tourist demand since 1995. The number of permanent Zancudo employees has been cut from 22 in 1994 (BMZ 1995a: 306) to only 7 today, although the remaining ones receive a higher real salary. Under the serious financial crisis of Transturi, ${ }^{21}$ the firm has also decided to cut back on the services and compensation payments that were originally agreed, which obviously has disturbed the relationship with the community that feels deceived by Transturi.

Many observers (e.g., in the Ecuadorian NGO community) see the current problems between Transturi and Zancudo as the failure of Transturi's 'patronisation' of local communities. However, it should be noted that the Transturi patronage role as such is much desired by the local people ${ }^{22}$ - a role that was formerly partly occupied by the Ecuadorian military.

An important point in question is that, compared to alternative cash sources, the people from Zancudo in fact receive substantial benefits from their cooperation with Transturi (Table 2). The main share (about $75 \%$ ) is derived from salaries and tips, ${ }^{23}$ and accrues to the employed individuals, the fixed 'hunting compensation' payments (that go to the communal purse), and related occasional services (accruing to individuals) make up the rest. The yearly total of 95088000 sucres (US\$ $32,233)$ received by 80 individuals constitutes a per capita tourism income of about US\$ 400/yr. Without doubt, this is a very substantial figure for a community, which has no other significant sources of cash income. ${ }^{24}$ The current discontent of the people from Zancudo is rather due to the income cutbacks relative to what is
Table 2. Zancudo tourism income

\begin{tabular}{|c|c|c|}
\hline Item & Composition & Total (sucres) \\
\hline Salaries $^{\mathrm{c}}$ & $\begin{array}{l}500000 \text { sucres } x \\
7 \text { persons (permanent } \\
\text { employment) } \\
143000 \text { sucres } x \\
8 \text { persons (day labourers) }\end{array}$ & 3500000 \\
\hline Tips $^{c}$ & $\begin{array}{l}90000 \text { sucres } x \\
11 \text { persons (pooled) } \\
80000 \text { sucres } x \\
6 \text { persons (personal) }\end{array}$ & $\begin{array}{l}990000 \\
480000\end{array}$ \\
\hline Food sold ${ }^{c}$ & 60000 sucres per month $^{\mathrm{b}}$ & 60000 \\
\hline Monthly total & & 6174000 \\
\hline Yearly total & $6174000 \times 12$ months & 74088000 \\
\hline \multirow[t]{3}{*}{$\begin{array}{l}\text { Services and } \\
\text { transfers } \\
\text { according to } \\
\text { LoA }^{c}\end{array}$} & $\begin{array}{l}\text { Food compensation: } \\
1000000 \\
\text { sucres/month } \\
\text { School uniforms, etc.: }\end{array}$ & 12000000 \\
\hline & $\begin{array}{l}500000 \text { sucres/month } \\
\text { Transport benefits: } \\
200000 \\
{\text { sucres } / \text { month }^{\mathrm{b}}}^{\mathrm{s}}\end{array}$ & 2400000 \\
\hline & $\begin{array}{l}\text { Medical services: } \\
50000 \text { sucres/month }\end{array}$ & 600000 \\
\hline $\begin{array}{l}\text { TOTAL } \\
\text { BENEFITS/ } \\
\text { YEAR }\end{array}$ & & 95088000 \\
\hline
\end{tabular}

Notes: ${ }^{a}$ US $\$ 1=2950$ sucres

b Own estimate of the corresponding value of alternatively purchased services

- Monthly figures

Sources: Field data and Transturi, Quito

perceived as a luxury operation - the average Flotel passenger spending is around US\$ 150 per day (BMZ 1995a: 285).

For the community of Playas tourism has a much more complementary role. No communal agreement exists with Transturi; however, the community is located close to the fixed Flotel route, which allows a number of Playas individuals to participate in this labour-intensive operation. In absolute terms, the yearly income flows for Playas (Table 3) reach an even marginally higher level than in Zancudo (96072000 sucres or US\$ 32 566). However, in relation to the larger size of the community (about 175 individuals), this only accounts for a per capita income from tourism of US\$ 184/yr. Furthermore, it must be remembered that the economy of Playas is far more commercial, so that both direct cash flows from the Flotel operation and local multiplier effects are largely restricted to those families whose members are actually employed by Transturi.

\section{THE COFANS OF ZÁBALO: AN AUTONOMOUS MODEL}

The Cofans are one of the indigenous groups that are native to Cuyabeno, i.e., that have not migrated into the 
Table 3. Playas de Cuyabeno tourism income ${ }^{a}$

\begin{tabular}{|c|c|c|}
\hline Item & Composition & Total (sucres) \\
\hline Monthly salaries ${ }^{c}$ & $\begin{array}{l}500000 \text { sucres } x \\
12 \text { persons (fixed } \\
\text { employment) } \\
143000 \text { sucres } x \\
2 \text { persons (day labourers) }\end{array}$ & 6000000 \\
\hline Monthly tips ${ }^{c}$ & $\begin{array}{l}90000 \text { sucres } x \\
14 \text { persons (pooled) } \\
80000 \text { sucres } x \\
4 \text { persons (personal) }\end{array}$ & $\begin{array}{r}1260000 \\
320000\end{array}$ \\
\hline Food sold ${ }^{c}$ & $\begin{array}{l}120000 \text { sucres } \\
\text { per month }\end{array}$ & 120000 \\
\hline Monthly total & & 7806000 \\
\hline Yearly total & $\begin{array}{l}7806000 \text { sucres } x \\
12 \text { months }\end{array}$ & 93672000 \\
\hline \multirow[t]{2}{*}{$\begin{array}{l}\text { Additional } \\
\text { services }^{c}\end{array}$} & $\begin{array}{l}\text { Medical services: } \\
50000 \text { sucres } / \text { month }^{b}\end{array}$ & 600000 \\
\hline & $\begin{array}{l}\text { Transport: } 150000 \\
{\text { sucres } / \text { month }^{\mathrm{b}}}\end{array}$ & 1800000 \\
\hline $\begin{array}{l}\text { TOTAL } \\
\text { BENEFITS/ } \\
\text { YEAR }\end{array}$ & & 96072000 \\
\hline
\end{tabular}

Notes: ${ }^{a}$ US $\$ 1=2950$ sucres

${ }^{b}$ Own estimate

${ }^{c}$ Monthly figures

Sources: Field data and Transturi, Quito

area in recent times. Since the 1970 s people from Dureno, the main Cofan community in the upper Aguarico river, have been taking backpackers on tourist trips to the Zábalo area. In 1984, a group of Cofans that had specialised in tourism decided to move permanently to the area, and founded the community of Zábalo (Buglass/PROBONA 1995: 91-4).

Part of this decision was the wish to maintain the traditional Cofan lifestyle of forest people, based on hunting, gathering and a minimum of food crops (plantains), but where tourism constitutes the only cash income. The 17 families (around 100 people) in Zábalo are not producing cash crops, cash timber or cattle. This exclusive dependency on ecotourism is a feature that is often criticised in the ecotourism literature; tourism should rather be a 'complement' within an array of diversified commercial activities. However, Zábalo has achieved excellent results with its specialisation and selfmanagement, and has gained many valuable experiences on the compatibility of tourism with a traditional indigenous lifestyle, which make Zábalo a fascinating case study.

Within the community, 10 people have started the programme 'Aguarico Trekking', organising rainforest tours of 9-10 days. A joint venture was established with Transturi in order to commercialise the product and leave the logistics of transport, food purchases and communication to the company. ${ }^{25}$ The logic was to specialise in what was perceived to be the comparative advantage of the Cofans - the local operation: one guest house, three jungle camps and about $60 \mathrm{~km}$ of trails were locally constructed; guides, food and local transport is provided. For Transturi, which mainly offers river-based tours, the trekking joint venture also constituted a diversification of their product mix.

A main element in understanding the success of Zábalo is its community leader Randall (Randy) Borman. As a son of missionaries, he grew up in the Amazon, studied later in the United States, and came back to marry a Cofan and live permanently in Zábalo. His knowledge of the 'two worlds' - the Western and the indigenous has been an important asset, in several respects. In the process of commercialisation, Randy was able to make direct contact with the agency Wilderness Travel to bring in North American tourists. Another cornerstone is the local organisation of the operation, which in its coordination requires planning, punctuality and reliability, plus an understanding of the preferences of Western tourists. These aspects have been serious limitations for other indigenous groups that have sought to establish autonomous operations, a point that is essential to understand the comparative success of the Cofans. Yet even in the case of Zábalo, tourism operation has been a learning process over the last 20 years. This may mean that they are not easily replicable in other communities, especially in the short run.

Until now, the idea of a joint venture has been a partial success. Promotion of the new product has only progressed very slowly, in part because of the high price (at US\$2300 for the 10-day tour, this is a luxury operation), but also because of Transturi's financial crisis. Zábalo has had to rely much on its former, USbased contacts. However, the logistical division of work seems to be functioning well.

As mentioned previously, only 10 people of Zábalo's 17 families are participating as 'shareholders' in Aguarico Trekking, which is an open but non-communal association. These people have been willing to invest capital and labour in the tourism business, and are hence sharing the current profits. The rest of the community receives benefits in terms of employment as cooks, guides, boatmen and porters, and from tips and the sale of handicrafts.

However, tourism income flows in Zábalo are not only derived from Aguarico Trekking, but also from various complementary services in relation to Transturi's Flotel operation. Two times a week, a group of Flotel tourists arrives at the Zábalo visitor centre, which is located across the river, apart from the village (so that 
detrimental social impacts can be avoided). A museum explains social and cultural aspects of traditional Cofan life, a community guide takes the group for a short jungle trip to explain medicinal plants and, at the end of the half-day excursion, Zábalo vendors sell locally produced handicrafts. This well-organised component of 'ethnotourism' is not only popular with the tourists, it also offers an important source of income for families that are not engaged in Aguarico Trekking - a fact that is recognised by the community who actively seeks to maximise and protect the tourist appeal of the visit. ${ }^{26}$

Given the large number of Flotel tourists (2560 in 1994), the economic impact of this component is in fact significant, as can be seen in Table 4 . The sale of handicrafts, a 'minor' business at first sight, is in fact the most important element (sales are higher for groups dominated by foreign than by Ecuadorian nationals). Transturi pays US\$ 2 for each Flotel tourist that participates in the visit, which provides an additional contribution to the Zábalo communal accounts. Other occasional services for the Flotel, such as food sales and transport, ${ }^{27}$ are of negligible importance.
In the Aguarico Trekking operation (see first part of Table 4), about $60 \%$ of local income accrues as profits to the shareholders. It is calculated that gross profits ${ }^{28}$ are about 10 million sucres for each tour, which are shared equally between Transturi and Zábalo. The rest is distributed between salaries, complementary local food sales, handicrafts and tips from each visit (currently, demand constraints limit activities to nine 10-day tours per year, a number which the members of Aguarico Trekking would like to see somewhat increased). Note that tips are high, and the local salary levels are also above those in other operations in Cuyabeno.

On aggregate, the total yearly income from tourism is quite high (145638000 sucres or US\$ 49369 ), especially compared to the small size of the community (per capita tourism income is US\$ 494). Yet this should be seen in the light of the complete village specialisation on tourism, the previous investments made by the community members, and the successively improving quality of the operation over the years. The size of Zábalo tourism income is higher than that recorded in previous studies ${ }^{29}$ and the share of the Flotel-related

Table 4. Zábalo yearly tourism income ${ }^{a}$

\begin{tabular}{|c|c|c|}
\hline Item & Composition & Total (sucres) \\
\hline Aguarico associates' profits & 5000000 sucres/tour $\times 9$ tours & 45000000 \\
\hline Salary assistants & $\begin{array}{l}60000 \text { sucres } \times 90 \text { days (cook) } \\
60000 \text { sucres } \times 90 \text { days (boatman) } \\
30000 \text { sucres } \times 90 \text { days (apprentice) } \\
30000 \text { sucres } \times 90 \text { days (2 porters) }\end{array}$ & $\begin{array}{l}5400000 \\
5400000 \\
2700000 \\
2700000\end{array}$ \\
\hline Salary guide & 60000 sucres $\times 90$ days & 5400000 \\
\hline Tips & 130000 sucres $\times 9$ persons $\times 9$ tours & 10530000 \\
\hline Handicrafts & 50000 sucres $\times 9$ persons $\times 9$ tours & 4050000 \\
\hline Food & 200000 sucres $\times 9$ tours & 1800000 \\
\hline $\begin{array}{l}\text { Total local income } \\
\text { Aguarico Trekking }\end{array}$ & & 82980000 \\
\hline Handicrafts Flotel & $\begin{array}{l}\text { Foreigner groups: }^{b} \\
{[500000 \text { sucres } \times 104 \text { visits }] \text { x 88\% }} \\
\text { National groups: }{ }^{b} \\
{[50000 \text { sucres } \times 104 \text { visits] } \times 12 \%}\end{array}$ & $\begin{array}{r}45760000 \\
624000\end{array}$ \\
\hline Flotel tourists' visits to museum & $\begin{array}{l}5900 \text { sucres }^{(U S \$ 2)} \times 2560 \text { tourists } \\
\text { from Flotel }^{\circ}\end{array}$ & 15104000 \\
\hline Other services related to Flotel & $\begin{array}{l}\text { Occasional sales of food: } \\
30000 \text { sucres/month } \times 12 \text { months } \\
\text { Occasional canoe transport: } \\
75000 \text { sucres } \times 24 \text { times } \times 45 \%{ }^{d}\end{array}$ & $\begin{array}{l}360000 \\
810000\end{array}$ \\
\hline $\begin{array}{l}\text { Total yearly income from } \\
\text { Flotel }\end{array}$ & & 62658000 \\
\hline $\begin{array}{l}\text { TOTAL TOURISM } \\
\text { INCOME/YEAR }\end{array}$ & $\begin{array}{l}\text { Aguarico Trekking and Flotel-related } \\
\text { services }\end{array}$ & 145638000 \\
\hline
\end{tabular}

Notes: a US\$ $1=2950$

b Percentages according to the frequency of foreigners and nationals in 1994 Flotel visitor distribution

c 1994 figures were used, as 1995 was extraordinarily affected by the war with Peru

d Only $45 \%$ of gross income (= labour cost); the other $55 \%$ is excluded (gasoline and oil $=40 \%$ and capital depreciation $=15 \%$ )

Sources: Field data and Transturi, Quito 
services (43\%) is considerable - a fact that previously has been entirely overlooked. ${ }^{30}$

The example of the Zábalo tourism operation is one of autonomy, and thus, compared to the Quichuas, at the other end of the spectrum of independence, responsibility and self-management. Nevertheless, it should be noted that Zábalo autonomy is not absolute, but achieved through a careful division of responsibilities with a large Quito-based agency, both in regard to the Aguarico joint venture and to its role in the Flotel operation.

\section{THE SIONA-SECOYAS: A SEMI- AUTONOMOUS MODEL}

In the Western part of the Cuyabeno Reserve, the indigenous groups of Secoyas and Sionas ${ }^{31}$ practise a type of tourism where certain local components, such as canoe transport, basic accommodation and nature guides, are provided independently by the local communities, although the responsibility for the entire operation remains in the hands of Quito-based agencies. In terms of the degree of autonomy, these operations thus occupy an intermediate position between the self-managed model of Zábalo and the salary-based relations in Zancudo and Playas.

The group of Secoyas probably migrated from Peru about half a century ago; the Sionas maintain links with the Colombian Amazon region to where they seem to migrate seasonally. However, the two groups have gradually intermarried, so that many studies treat them as a single ethnicity. In the following discussion, we will examine the cases of San Pablo de Kantesiya and Puerto Bolívar, both of which participate in tourism operations.

San Pablo, a Secoya community of about 150 people, is located just outside the borders of the Cuyabeno Reserve, in an area where deforestation and forest degradation are advanced. Only 90 minutes by canoe from the road in Chiritza, the area has suffered high pressure from squatters, loggers and African palm plantation farmers. ${ }^{32}$ Consequently, the productive model of the Secoyas has also more come to resemble the colonos: a commercially oriented economy, based on coffee, cocoa, cattle and, occasionally, timber extraction.

Because of external and internal pressures (including overhunting), flora and fauna in the area around San Pablo are no longer of particular tourist interest. This also means that tourist groups only stay for a couple of days in the village, applying more of an 'ethnotourist' focus; the major and more nature-oriented part of the average tour of 7-10 days is spent in the remote but pristine area of Lagartococha, near the border to Peru. ${ }^{33}$ In other words, the ecotourism area is separated from the productive area of San Pablo, which has a different bearing on land use decisions (see section on environmental impacts).

Since 1988, San Pablo has cooperated with the Quitobased agency Etnotur. As in the case of Transturi, the agreement between Etnotur and San Pablo contains not only salary payments and tour-related services, but also a number of fixed benefits and the availability of health and transport services. ${ }^{34}$ However, unlike the Transturi case, locals are also employed as native guides, and the two tourist canoes with outboard motors are owned, operated and maintained by two individuals from the community, although originally, they had been purchased by Etnotur - a model of responsibilities and income incentives that has proved to be beneficial for both sides. ${ }^{35}$

The economic arrangements between the Secoyas of San Pablo and Etnotur (Table 5) involve a fixed payment for each tourist that enters the community area and limited sales of handicrafts and food items. For about half of the tours, locals also offer cultural performances (a traditional dance and a demonstration of ancient hunting techniques). However, the most important categories are clearly the salaries paid to indigenous guides and assistants, plus river transport - in particular motorised canoes. ${ }^{36}$ In addition, a value had to be computed for the complementary services (health, transport, etc.) that Etnotur provides, independent of the number of tourists that enter (representing $15.2 \%$ of total income).

Compared to Zábalo, Zancudo and Playas, total income of 42770000 sucres/yr (US\$ 14 498/yr) is rather modest (a per capita income of a US\$ 100/yr). However, it should be remembered that Etnotur is a much smaller agency than Transturi, organising only two trips per month, with an average of five tourists each. Consequently, tourism also has a more marginal and complementary role in the economy of San Pablo.

The Siona-dominated village of Puerto Bolívar retains a productive structure that somewhat resembles Zábalo. Its approximately 140 people mainly practise hunting, gathering and subsistence agriculture; cash income flows are derived from tourism. However, cattle have been introduced on a small scale (2-3 head per family), except for a couple of families with a much higher cattle tenancy.

Puerto Bolívar is strategically located in the vicinity of the Cuyabeno lakes, the area with the highest tourism density within the Reserve. Depending on the season, 
Table 5. San Pablo tourism income (calculated per operated tour and annually) ${ }^{a}$

\begin{tabular}{|c|c|c|}
\hline Item & Composition & Total (sucres) \\
\hline Community transfer & 15000 sucres $\times 5$ tourists & 75000 \\
\hline Salary assistants & 10000 sucres $\times 8$ days $\times 3$ persons & 240000 \\
\hline Salary guide & 20000 sucres $\times 8$ days & 160000 \\
\hline \multirow{2}{*}{$\begin{array}{l}\text { Transport (canoes with/without } \\
\text { motor) }\end{array}$} & 150000 sucres $\times 6$ days $\times 45 \%$ (net) & 405000 \\
\hline & 5000 sucres $\times 8$ times & 40000 \\
\hline Tips & 80000 sucres $\times 5$ persons & 400000 \\
\hline Handicrafts & 20000 sucres & 20000 \\
\hline Food & 25000 per tour & 25000 \\
\hline Cultural services & $(50000+10000) / 2$ sucres & 30000 \\
\hline Total income/tour & & 1395000 \\
\hline Total income/year & 1395000 sucres $\times 26$ tours/year & 36270000 \\
\hline \multirow[t]{4}{*}{ Independent yearly services } & Medical services, etc $=$ & 4000000 \\
\hline & Air tickets, lodging Quito, etc. & 1500000 \\
\hline & Contribution to local celebrations ( 2 x yearly) & 500000 \\
\hline & Other items & 500000 \\
\hline TOTAL TRANSFER/ YEAR & & 42770000 \\
\hline
\end{tabular}

14-20 agencies are currently operating in the lakes area, on an occasional to regular basis. The popularity of the site has given the Sionas a good bargaining position for the generation of local tourism income, which has been supported by INEFAN and by the GTZ-implemented PROFORS project. The Sionas pretend to provide the only motorised canoe transport on the lakes, which is a lucrative business with the large number of agencies operating. Yet, according to several of the agencies, this has artificially driven up prices and lowered the reliability of river transport. Hitherto, problems of local organisation have meant that some agencies have been allowed to provide their own transport, so that the monopoly is not in full operation.

In contrast to Zábalo where commercialisation and external logistics have been left to the agencies, the Sionas in Puerto Bolívar have the ambition to create a fully independent operation with their own channels of commercialisation. In order to attract tourists, an office was created in the provincial capital of Lago Agrio and external aid has been provided. However, this autonomous Siona operation (and its external support) is criticised by the Quito tourism operators for being unauthorised and tax-evasive. ${ }^{37}$

Because of the large number (and varying origins) of operators on the Cuyabeno lakes, we have been unable to explicitly study all of them. The figures for two of the most important agencies, Nuevo Mundo and Neotropic, were examined (Table 6). Even this limited evidence makes it clear that the motorised canoe transport is a major source of income (36\% of the total). Salaries to native guides and assistants are also important (31\%), whereas food and handicraft sales and the 'rent-a-roof' type of hut accommodation provided by the Sionas are marginal. ${ }^{38}$ The considerably higher local income generation by Neotropic, as compared to Nuevo Mundo, seems to be the result of their employment of Siona assistants, which has been a sensitive issue. ${ }^{39}$ The yearly local income derived from the two agencies' operation is 57575000 sucres (US\$ 19 517).

Although this is a substantial amount, we can only conjecture about the total income size, i.e., including the impact of other agencies. The calculations in Table 6 correspond to an expenditure of US\$ $19517 / 620$ tourists $=$ US\$ 31.48 per tourist. If we conservatively assume that only the above $36 \%$ of the total cost, equal to US\$ 11.33 , is captured through the monopolised canoe transport of the remaining 1380 Cuyabeno lake tourists, ${ }^{40}$ this would yield US\$ 15635 additional yearly income. According to this calculation, total tourism income in Puerto Bolívar would thus be $19517+15365=$ US\$ 35 152. Although this figure remains speculative, it illustrates that the high number of tourists visiting the 
Table 6. Puerto Bolívar yearly tourism income, from collaboration with Nuevo Mundo and Neotropic agencies ${ }^{a}$

\begin{tabular}{|c|c|c|}
\hline Item & Composition & Total (sucres) \\
\hline Salary assistants & $\begin{array}{l}\text { Neotropic: } \\
350000 \text { sucres } \text { x } 12 \text { months (permanent } \\
\text { employment) } \\
15000 \text { sucres } \times 250 \text { days ( } 2 \text { day labourers) }\end{array}$ & $\begin{array}{l}4200000 \\
7500000\end{array}$ \\
\hline Salary guides & $\begin{array}{l}\text { Nuevo Mundo: } \\
30000 \text { sucres } \times 55 \text { tours } \times 2 \text { days } \\
\text { Neotropic: } \\
30000 \text { sucres } \times 50 \text { tours } \times 2 \text { days }\end{array}$ & $\begin{array}{l}3300000 \\
3000000\end{array}$ \\
\hline \multirow[t]{2}{*}{ Transport (motorised canoes) } & $\begin{array}{l}\text { Nuevo Mundo: } \\
140000 \text { sucres } \times 4 \text { days } \times 55 \text { tours } \\
=30800000 \text { sucres (gross income) } \\
\text { Net income }(45 \%=\text { labour cost) }\end{array}$ & 13860000 \\
\hline & $\begin{array}{l}\text { Neotropic: } \\
140000 \text { sucres } \times 4 \text { days } \times 50 \text { tours } \\
=28000000 \text { sucres (gross income }) \\
\text { Net income }(45 \%=\text { labour cost })\end{array}$ & 12600000 \\
\hline Tips $^{c}$ & $\begin{array}{l}\text { Nuevo Mundo } \\
30000 \text { sucres } \times 1 \text { person } \times 55 \text { tours } \\
\text { Neotropic } \\
30000 \text { sucres } \times 3 \text { persons } \times 50 \text { tours }\end{array}$ & $\begin{array}{l}1650000 \\
4500000\end{array}$ \\
\hline Handicrafts $^{c}$ & $\begin{array}{l}\text { Nuevo Mundo: } \\
20000 \text { sucres } \times 55 \text { tours } \\
\text { Neotropic: } \\
40000 \text { sucres } \times 50 \text { tours }\end{array}$ & $\begin{array}{l}1100000 \\
2000000\end{array}$ \\
\hline Lodging ('rent-a-roof') & $\begin{array}{l}\text { Nuevo Mundo: } \\
110 \text { tourists } \times 2 \text { nights } \times 7000 \text { sucres }\end{array}$ & 1540000 \\
\hline \multirow[t]{2}{*}{ Food } & $\begin{array}{l}\text { Nuevo Mundo: } \\
15000 \text { sucres } \times 55 \text { tours }\end{array}$ & 825000 \\
\hline & $\begin{array}{l}\text { Neotropic: } \\
30000 \text { sucres } \times 50 \text { tours }\end{array}$ & 1500000 \\
\hline \multirow[t]{2}{*}{$\begin{array}{l}\text { TOTAL YEARLY } \\
\text { INCOME }\end{array}$} & $\begin{array}{l}\text { Nuevo Mundo: } \\
\text { Neotropic: }\end{array}$ & $\begin{array}{l}26475000 \\
31100000\end{array}$ \\
\hline & TOTAL: & 57575000 \\
\hline
\end{tabular}

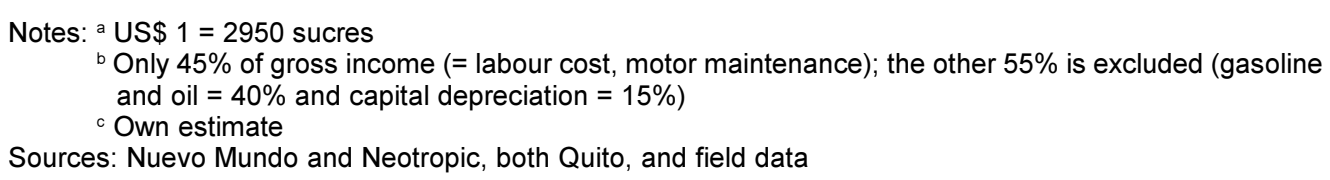

Cuyabeno lake area may guarantee cash inflows that are not greatly inferior to those produced in Zábalo.

\section{A COMPARISON OF LOCAL TOURISM INCOME FLOWS}

The first hypothesis set out in the beginning of this study proposed that there would be a systematic difference in the size of local tourism income, determined by the degree of autonomy in tourism participation. Quantifying the yearly cash flow for each of the five communities analysed allows a comparison of the size and structure of income (Table 7).

First, if we compare the estimates in Table 7 with the earlier, rough estimations made by Ceballos-Lascuráin (1993: 53-8), the present totals are generally much higher: Zábalo US\$ 49430 (Ceballos: US\$ 20000 30,000); Playas and Zancudo together about US\$ 65000
(Ceballos: US\$ 35 000) and US\$ 19500 (2 agencies) up to perhaps US\$ 40000 (total) for Puerto Bolívar (Ceballos: US\$ 15 000-20,000). ${ }^{41}$ This indicates that it is beneficial to make a full, explicit analysis of cash flows.

The structure of tourist incomes, as indicated by the varying percentage shares in Table 7 , illustrates the different participation models: assistant wage categories dominate in Zancudo and Playas; boat transport is most important in Puerto Bolívar and San Pablo; and handicraft sales and corporate profits dominate in Zábalo. It is noteworthy that derived sales, such as food (generally insignificant) and handicrafts (only for Zábalo) currently play a very limited role - this may offer a future potential for raising local income.

The income totals in the five study sites vary from US\$ 15000 to US\$ $50000 / y r$. However, the per capita 
Table 7. Comparing local tourism income in Cuyabeno villages (yearly figures in \$US) ${ }^{\text {a }}$ Percentage share of total income in parentheses

\begin{tabular}{|c|c|c|c|c|c|}
\hline Item & Zancudo & Playas & Zabalo & San Pablo & Puerto Bolivar ${ }^{b}$ \\
\hline Associates' profits & - & - & $\begin{array}{c}15254 \\
(30.9 \%)\end{array}$ & - & - \\
\hline Salary assistants & $\begin{array}{c}18891 \\
(58.6 \%)\end{array}$ & $\begin{array}{c}25570 \\
(78.5 \%)\end{array}$ & $\begin{array}{c}5492 \\
(11.1 \%)\end{array}$ & $\begin{array}{c}2115 \\
(14.6 \%)\end{array}$ & $\begin{array}{c}3966 \\
(20.3 \%)\end{array}$ \\
\hline Salary native guides & $-d$ & - & $\begin{array}{c}1831 \\
(3.7 \%)\end{array}$ & $\begin{array}{c}1410 \\
(9.7 \%)\end{array}$ & $\begin{array}{c}2125 \\
(10.9 \%)\end{array}$ \\
\hline Canoe transport $^{\mathrm{C}}$ & - & - & $\begin{array}{c}336 \\
(0.7 \%)\end{array}$ & $\begin{array}{c}3922 \\
(27.1 \%)\end{array}$ & $\begin{array}{c}8969 \\
(46.0 \%)\end{array}$ \\
\hline Tips & $\begin{array}{c}5980 \\
(18.6 \%)\end{array}$ & $\begin{array}{c}5695 \\
(17.5 \%)\end{array}$ & $\begin{array}{c}3569 \\
(7.2 \%)\end{array}$ & $\begin{array}{c}3525 \\
(24.3 \%)\end{array}$ & $\begin{array}{c}2087 \\
(10.7 \%)\end{array}$ \\
\hline Handicrafts & - & - & $\begin{array}{c}17096 \\
(34.6 \%)\end{array}$ & $\begin{array}{c}176 \\
(1.2 \%)\end{array}$ & $\begin{array}{c}1051 \\
(5.4 \%)\end{array}$ \\
\hline Lodging huts & - & - & Included $^{d}$ & - & $\begin{array}{c}522 \\
(2.7 \%)\end{array}$ \\
\hline Food sales & $\begin{array}{c}244 \\
(0.8 \%)\end{array}$ & $\begin{array}{c}488 \\
(1.5 \%)\end{array}$ & $\begin{array}{c}732 \\
(1.5 \%)\end{array}$ & $\begin{array}{c}220 \\
(1.5 \%)\end{array}$ & $\begin{array}{c}788 \\
(4.0 \%)\end{array}$ \\
\hline Other items & - & - & $\begin{array}{c}5120^{\mathrm{e}} \\
(10.4 \%)\end{array}$ & $\begin{array}{c}925^{f} \\
(6.4 \%)\end{array}$ & - \\
\hline Total tour income & $\begin{array}{l}25115 \\
(77.9 \%)\end{array}$ & $\begin{array}{c}31753 \\
(97.5 \%)\end{array}$ & $\begin{array}{l}49430 \\
(100 \%)\end{array}$ & $\begin{array}{c}12293 \\
(84.8 \%)\end{array}$ & $\begin{array}{c}19508 \\
(100 \%)\end{array}$ \\
\hline Services by agreement & $\begin{array}{c}7118 \\
(22.1 \%)\end{array}$ & $\begin{array}{c}813 \\
(2.5 \%)\end{array}$ & - & $\begin{array}{c}2205 \\
(15.2 \%)\end{array}$ & 0 \\
\hline TOTAL INCOME & $\begin{array}{l}32233 \\
(100 \%)\end{array}$ & $\begin{array}{l}32566 \\
(100 \%)\end{array}$ & $\begin{array}{l}49430 \\
(100 \%)\end{array}$ & $\begin{array}{r}14498 \\
(100 \%)\end{array}$ & $\begin{array}{c}19508 \\
(100 \%)\end{array}$ \\
\hline Inhabitants $^{g}$ & 80 & 175 & 100 & 150 & 140 \\
\hline Per capita income ${ }^{h}$ & 403 & 186 & 494 & 97 & 139 \\
\hline
\end{tabular}

Notes: ${ }^{a}$ US $\$ 1=2950$ sucres

b Only income from collaboration with Nuevo Mundo and Neotropic agencies

c Only $45 \%$ of gross income (= labour cost, motor maintenance); the other $55 \%$ is excluded (gasoline and oil = $40 \%$ and capital depreciation $=15 \%$ )

d Remuneration included in the tour price

e Payment of US\$ 2 for each Flotel passenger that visits the Zábalo museum

${ }^{f}$ Includes cultural services and a US\$ 5 payment for each tourist that arrives in the community

g Approximate population data, based on field interviews

h Calculated as total income/inhabitants

Sources: Field data and travel agents, Quito

income may give a better indication of the relative importance of tourism in the local economy. Note that these figures do not support the hypothesis of higher income through higher autonomy. The salary model of Zancudo, with about US\$ 400 per capita, produces only marginally less income than the self-management model of Zábalo, and the intermediate model of Puerto Bolívar probably yields an income total that is not much inferior.

The site-specific differences that we observe rather seem to be determined by varying degrees in the specialisation on tourism. ${ }^{42}$ Zancudo, Zábalo and Puerto Bolívar can rely on attractive natural sites in order to make tourism a way of living. In turn, Playas de Cuyabeno and San Pablo practise a model of cash crop and cattle-oriented production in previously degraded areas, and have found a niche within the tourism business to complement their incomes.
However, even in the case of Playas and San Pablo, it is obvious that employment in tourism is a very competitive source of income generation. As both villages have commercialised economies, local day labour rates (jornales) that are used between villagers for occasional labour exchange are good indicators for the remuneration from alternative employment opportunities. ${ }^{43}$ In Playas, the correspondent daily pay rate offered for permanent employment in the Flotel (19 230 sucres $)^{44}$ is about double the rate of the local jornal (10 000 sucres)..$^{45}$ In San Pablo, the local jornal is 50008000 sucres; ${ }^{46}$ this compares to the day remuneration of assistants (10 000 sucres), nature guides (20 000 sucres) and self-employed boatmen (67 500 sucres) ${ }^{47}$

For Zancudo and Zábalo, the corresponding argument is even more evident: the de facto absence of other local cash-generating activities limits the alternatives of monetary income sources to temporary migration. For 
Puerto Bolívar, only a small number of families receives cattle-based incomes that are competitive; the majority of cash flows comes from tourism.

This leads us to an important general conclusion about the size and generation of local tourism income:

Conclusion 1: In all five study cases of tourism in Cuyabeno, local community members receive economic benefits that are significant and competitive, compared to other sources of monetary income. Income differences between communities cannot be explained by their different degree of autonomy from tourist agencies; rather they are the product of different degrees of tourism specialisation.

Note that this conclusion does not refer to the 'vertical' distribution of tourism income, i.e., the issue of fairness in overall profit sharing between agency and community, which we deliberately are not trying to address in the present work. ${ }^{48}$ However, we can say that our data do not lend support to those that believe in a relation of 'exploitation' by the agencies, i.e., that autonomously operating communities would clearly be better off than the salary-receiving ones.

An area where differences between salary employment and autonomy actually can be observed is the problem of economic incentives: in the long run, the gradual transfer of ownership and responsibility towards local community members ${ }^{49}$ is beneficial for the quality of the tourist operation. Or, expressed in a different manner, the lack of incentives in a static salary-based relationship creates a number of difficulties. This was confirmed in the cases of assistants, ${ }^{50}$ local guides ${ }^{51}$ and boatmen. ${ }^{52}$ It is also obvious that the level of personal work satisfaction increases with the degree of responsibility and with the opportunities to expand it gradually. In general, it seems that the longer the time horizon of cooperation between agencies and communities, the more likely is the former to integrate the latter in a progressively responsible role. ${ }^{53}$

\section{SOCIOECONOMIC IMPACTS}

In this section, we will not address the entire spectrum of social impacts related to tourism in Cuyabeno; rather, we will focus on social factors as an essential link between the economic and environmental impacts of tourism, vis-à-vis Figure $1 .{ }^{54}$ If the additional income from tourism is associated with a socially unacceptable development pattern, the expected positive conservation impact may not ensue. On the transition path from tourism economics and income to socioeconomic impacts, factors such as inequality, consumption patterns and local inflation effects may be of vital importance.
Perhaps the single most critical factor is income distribution. Emergence of a new productive activity within the framework of a traditional economy should be expected to create inequality. Individuals have different preconditions, motivations, speed and energy to respond to new options for income generation; it would be naïve to expect that every individual could immediately take equal advantage. Short-run inequalities are thus not necessarily worrisome, and may not require any particular intervention. It is more important to secure that, in the medium term, there is diffusion of knowledge, opportunities and income (through training, credit access, rotation schemes, etc.). ${ }^{55}$

Among our case studies, the most unequal distribution of tourism income occurs in Puerto Bolívar, where activities are concentrated in the hands of two dominant Siona families. Although this dominance is traditional, it seems clear that tourism has accentuated it further. In particular, subsidised credit from the agencies to one family for the purchase of outboard motors has concentrated power, which is perpetuated by limiting the number of canoes allowed to operate on the Cuyabeno lakes. There seem to be no 'automatic stabilisers' which currently would be able to reverse this trend.

In the Quichua communities of Zancudo and Playas, almost all benefits are related to Transturi employment. There is a huge difference in Transturi's remuneration of permanent employees and day labourers - the former receive four times the salary of the latter. This gap, hardly justifiable in productivity terms, creates jealousy between the two groups. Additionally, some interviews indicated that the monthly compensation payments of 1 000000 sucres from Transturi to the community is not equally distributed, due to internal problems of community organisation.

In Zábalo, there is a basic inequality between the Aguarico Trekking associates (who share net profits) and the rest of the community (who receives benefits from employment and handicraft sales). ${ }^{56}$ However, as the company is an open society, disparities reflect the different entrepreneurial preferences inside the community, rather than a process of exclusion led by dominant families, as in the case of Puerto Bolívar.

In San Pablo, the community has decided to create a job rotation scheme for achieving an equitable distribution of employment benefits. Obviously, this does not apply to the lucrative business of river transport, which is permanently concentrated in the hands of the two individuals that own outboard motors.

Cultural impacts of tourism tend to be highly complex, but the interviews indicated in general that most effects 
were perceived as positive by local residents: elements of traditional culture tend to be revalued, especially where they become an 'ethnotourist' element of commercialisation (Zábalo, San Pablo). The encounter with the tourist is mostly seen as a positive experience of cultural exchange. However, it is obvious that increased contacts with the outside world tend to introduce foreign elements, not only in terms of 'Westernisation', but also by criollo culture (Spanish tends to replace local tongues) and in-migrant indigenous cultures. ${ }^{57}$ As a side effect, some communities have become more exposed to exotic diseases borne by Western tourists, such as influenza.

Another potentially harmful side effect of tourism-led demand is local inflation. It was shown for the case of Belize that tourism income and demand may raise the prices of labour, land and locally produced goods (Lindberg and Enriquez 1991: 70-1). In the Cuyabeno Reserve, private land property and its commercialisation are not allowed inside the protected area. With regard to the impact on local production, there is basically no competition for goods, e.g., almost all foodstuffs are brought in from outside the region.

The only inflationary effect can be observed in terms of labour time; as shown in the previous section, locally paid wages have risen, e.g., in order to have neighbours to take care of a farm while a resident works in tourism. Consequently, some extremely time-consuming activities may have to be abandoned. It also seems to have had a gender impact, in the sense that tourism employment is almost exclusively confined to men, while women are left with more work and greater responsibilities in domestic affairs. It can be argued that increasing wages is a natural process related to the opening up of new employment opportunities that yield a higher remuneration. They should only be seen as a social problem if the benefits from tourism are extremely unequally distributed.

Our cash flow analysis above showed that all five communities received significant income from tourism. To what degree did these incomes substitute for other cash inflows, and to what degree were they additional? Does additional income tend to stimulate savings or consumption and, in the latter case, what type of goods are being purchased?

It would probably take a prolonged investigation in situ to give definitive answers to these questions; however, our rapid field assessment allows us identify the main trends. In the more remote villages of Zábalo, Zancudo and Playas, where tourism income is mainly supplementary, ${ }^{58}$ no clear change in the consumption of food items or other current costs is observed. The situation is different for the villages which are located closer to the markets, with lower transport costs (Puerto Bolívar, San Pablo); a higher consumption of externally purchased food items was generally recorded, such as rice, sugar, occasionally clothes and notably alcohol..$^{59}$ Note, however, that in these villages, it proves difficult to distinguish between the specific impacts of tourism and ongoing commercialisation trends per se.

In several of the communities (Playas, Zábalo, Zancudo), it was noted that tourism-induced changes in resource management were not so much a direct consequence of additional income and a reduced 'push' towards degrading subsistence practices, but rather of reduced time availability. Ancient traditions, such as going deep into the forest for hunting for a couple of weeks, tend to diminish or disappear. The regular arrival of tourists and the employment offered by tourist agencies call for a different organisation and a more explicit planning of daily life, which leaves less time and opportunity for improvisation.

However, if most of the villages have maintained their previous consumption patterns, how is tourism income actually used? It seems that a large part has been spent on consumer durables, e.g., radios, solar energy cells and, particularly, outboard motors - besides being symbols of social status, they significantly ease mobility in river transport. A portion of income was also reported to have been saved. One purpose of savings is the financing of children's education in the cities. Obviously, this enhances the possibility that young people will not return to the community, which exemplifies the complex character of social changes activated by the cash inflow from tourism - or indeed from any other commercial activity.

\section{ENVIRONMENTAL IMPACTS}

The environmental impact of tourism in the Cuyabeno Reserve is a controversial subject. Based on somewhat scattered evidence, studies by Calvopiña and Calvopiña (1993) and Paz y Miño (1990) both warn about the environmental dangers related to tourism, and call urgently for regulation of the sector. Ceballos-Lascuráin (1991) goes one step further in his advocacy: both the number of tourists and infrastructure development in Cuyabeno should be frozen at their present levels, until a monitoring system for the determination of 'limits of acceptable change' $(\mathrm{LAC})^{60}$ has been established.

On the other hand, the environmental impact study of the Flotel Orellana operation by Ulloa (1994) identifies a number of minor impacts (increased waves, trail 
erosion), but concludes on aggregate that current impacts do not threaten the integrity of the Reserve. Correspondingly, the BMZ study on Cuyabeno (BMZ 1995a: 295) concludes that negative tourism impacts are still limited, and that the number of tourists may be increased, as long as this is done in a well-planned manner.

It is likely that the tourist operations of some agencies, in particular in the Cuyabeno lake area, and with special reference to poaching, have an adverse environmental impact. However, current research on the tourism impact on flora and fauna will produce more consolidated and scientific knowledge. ${ }^{61}$

However, our objective is not to discuss the entire topic of environmental tourism impacts; rather, we would like to focus on the specific incentive link between tourism income and conservation that were described in Figure 1. Three questions may be recalled from the discussion early in this paper, relating both to internal and external resource pressures. Will tourism income lead to substitution in local production patterns? Will they trigger a more pronounced environmental awareness and sustainability in existing local resource management practices? And, finally, are they able to strengthen the power of local interests to fight external environmental threats?

Before trying to answer these questions on local resource pressures, one may challenge the view that they should in fact be included in the analysis. Indeed, our interviews with some tourism operators confirmed that the traditional practices of local communities are often viewed as 'sustainable by nature'; this coincides with the dominant view in INEFAN's protected area management that local resource uses are legitimate, as long as they can be labelled 'traditional'.

In the case of Cuyabeno, the validity of this view is complicated by the fact that recent in-migration from non-native indigenous groups has occurred (Quichuas, Shuars), that some groups (Quichuas, Sionas, Secoyas) have diversified into non-traditional activities (cattle and cash crops) and several communities confirmed the problem of increased site-specific pressure on certain mammals by overhunting. ${ }^{62}$ This means that both overhunting (as a 'traditional' activity) and deforestation for cattle ranching/cash crops (as a 'non-traditional' one) have to be considered internal environmental pressures in Cuyabeno.

From a conservationist point of view, the most encouraging case of tourism cum conservation is Zábalo. The high degree of community organisation has allowed for the adoption of a zoning scheme, prohibiting hunting in specified areas that are set aside for tourism. Additionally, certain threatened species have been completely protected (and the common practice of dynamite fishing has been prohibited). For other species, a monthly maximum hunting quota per family has been determined. In certain cases where the violation of these rules has been proved, individuals have in fact been subjected to communal fines.

Behind this decision has been the dual recognition that hunting in fact causes a pressure on selected species (i.e., that faunal resources are not infinite), and that this poses a threat to tourism as 'the goose that lays the golden eggs' (i.e., that a trade-off in local resource management exists). An interesting feature is that the self-imposed restrictions on hunting have not turned the inhabitants of Zábalo into mass consumers of canned tunafish and corned beef. The amount of game consumed by the villagers seemingly has not been dramatically reduced, but there has been a substitution of species and the areas of origin.

Consequently, the case can be made that tourism has helped both to preserve the traditional Cofan lifestyle and to improve villagers' welfare (without having to turn to cattle ranching and cash crops), by conserving wildlife under what a land use planner would call 'a rationalised use under growing resource scarcity'. It thus appears to be a successful example of 'sustainable use' and 'winwin' type of conservation through ecotourism.

Of course, this verdict ultimately depends also on the definition of conservation goals. For instance, a shift in hunting practices that alleviates pressures on selected species that are important for tourism may, conversely, increase the stress on other hunted species with important ecosystem functions. In other words, there is no guarantee of a full concurrence between tourism-related conservation goals and the broader biodiversity conservation objectives of a protected area. However, in the case of Cuyabeno where the hunting of mammals and birds and the incipient forest conversion to alternative uses are the main local threats to forest integrity, it should be expected that tourism-determined conservation concerns and the broader protection priorities of the park significantly overlap.

In Zancudo, another community that depends heavily on tourism income, the zoning of and restrictions on hunting have not been self-developed by the community, but rather imposed from outside as a precondition for cooperation with Transturi. As community members will receive their salary whether the tourist sees wildlife or not, there has not been the same direct incentive as in 
Zábalo to enforce restrictions. Obviously, the community has a long-term interest in the continuity and success of Transturi's operation, but it seems that Zancudo residents do not at present perceive a clear and direct link between hunting, tourism decline and own income losses.

The concept of 'protein substitution' that has been applied by Transturi (compensating hunting restrictions with the monthly compensation by one head of cattle) $)^{63}$ has not been very efficient, because of the difficulties of monitoring hunting restrictions. Nevertheless, there has been a reduction in hunting. According to the interviews, this is - as in the other cases of villages specialised on tourism (Zábalo, Puerto Bolívar) - mainly due to the reduced labour time available for prolonged hunting trips. However, whether this more random reduction has the same conservationist effect as the (targeted) zoning in Zábalo remains debatable.

In Puerto Bolívar, the third village with a clear tourism specialisation, there has also been a process of zoning as a response to the intensive tourism in the Cuyabeno lake area. However, this has not been a communal initiative, but a precondition set out by the park authorities in order to legalise Siona land occupation.. Zoning has been worked out in a participatory process that included the assistance of the GTZ project PROFORS. In terms of implementation, it seems that the community has accepted the hunting restrictions in the Cuyabeno lake area. However, the regulations relating to timber extraction are not fully respected. ${ }^{64}$

In San Pablo, the income from tourism has also raised consciousness about the value of natural resources. However, as the nature attractions of the operation are located in Lagartococha, i.e., remote from their own village, this has not had any impact on the productive activities in San Pablo. ${ }^{65}$ As tourism remains a minor activity, there has not been a substitution impact of reduced labour time. The same is true for the people from Playas, who are not currently carrying out tourist operations near the village, which would give them an incentive to change or substitute current productive activities.

These two examples show that only when the tourism operation physically coincides with the area of extractivism or production will there be a trade-off in terms of land use that produces an incentive for conservation; the same applies for competing uses of labour time. One can also reverse the argument. Only when the adjacent natural area is still sufficiently pristine to present flora and fauna of tourist appeal will it be possible to use it for ecotourism. Conversely, if the area is already heavily degraded one cannot expect a conservationist link.

With reference to the expectations discussed in the first section of the paper, one could ask if there is a 'proportionality' between, on the one hand, the size of local tourism income and, on the other, the degree of change in local conservation attitudes and the vigour of implementation of conservation efforts. For example, in Zábalo we recorded the highest per capita tourism income and at the same time the most far-reaching changes in the resource management system.

Nevertheless, it is an oversimplification to expect a straightforward relationship, as tourism's economic impact is only one of a number of factors, which seem to determine the degree of nature conservation at the local level. These include:

- natural resource pressures from external actors (oil companies, squatters, etc.);

- ethnic, historical and cultural differences;

- distance from urban markets;

- demographic pressures; and

- organisational capacity within the community.

Finally, severe external pressures exist, at least in the medium and long terms, to allow for oil exploration and exploitation in the Cuyabeno area. According to the experiences in other parts of the Ecuadorian Amazon region, once a new area has been 'opened up' by penetration roads, it proves impossible for the State to protect the area from loggers, squatters and plantation farmers. This is an environmental threat that by far outweighs any detrimental impacts that may currently be caused by tourism operation. ${ }^{66}$

There are good reasons to believe that the rise of tourism and the stream of income accruing not only to the agencies, but also to the Ecuadorian State, ${ }^{67}$ have substantially helped to conserve the integrity of the Reserve. A good example is the protagonist role played by Transturi in the large extension of the Reserve in 1991: without the active lobbying from an economically powerful actor, it is very unlikely that the Cuyabeno Reserve would have been enlarged so drastically. In this respect, some indigenous groups, like the Cofans, view Transturi as an important strategic ally in the defence of its territory against external pressures. ${ }^{68}$

Recently, the so-called 'Association for the Defense of Cuyabeno', has united a heterogeneous but innovative mix of actors, such as indigenous groups, environmentalists and tourist operators. One of the partial successes that the association has already achieved is a Presidential decree that prohibits oil-related 
activities in the Imuya zone - perhaps the area with the highest biological diversity in Cuyabeno - in order to protect its tourist values. ${ }^{69}$ It is too early to tell whether this alliance can resist the powerful oil interest in the long run, but its results hitherto have been remarkable. On aggregate, there can be no doubt that tourism and its local income generation have played an important role in the protection of the Cuyabeno Reserve. However, not all of the supposed three links that have been described in Figure 1 have materialised. There has been no substitution of ongoing degradation activities (cattleled deforestation, timber and cash crop sales); rather, where degradation has already advanced, ecotourism is unlikely to be more than a complementary activity without local productive impacts. The results can be summarised as follows:

Conclusion 2: Tourism income in Cuyabeno has helped to protect the area against strong external pressures. Tourism is unlikely to radically change commercialised, degrading resource-use patterns once these have reached an advanced stage of development. However, in villages with an early tourism specialisation, tourism has raised environmental awareness and facilitated the adoption of zoning and other regulation schemes, which, together with a tourism-induced reallocation of labour time, have reduced local overhunting and other degradation of natural resources.

\section{CONCLUSIONS AND RECOMMENDATIONS}

One of the principal criteria for classifying so-called 'ecotourism' is that the local population at the site should receive substantial income from their tourism participation. This would foster distributive justice and local support to the operation, and would provide economic incentives for conservation. In the present paper, the supposed link between tourism, local income and conservation was conceptualised (see Figure 1) and tested, for the case of the Cuyabeno Wildlife Reserve in the Ecuadorian Amazon region. The study data were collected through semi-structured interviews of local residents, consultations with operators and travel agencies in Quito, and in situ observation of tourism practices.

The three main Cuyabeno ethnic groups involved in tourism, the Quichuas, Cofans and Siona-Secoyas, are characterised by different tourism participation models, with different degrees of autonomy in their operation. A frequently applied hypothesis is that a higher degree of autonomy is also accompanied by higher local income (see Hypothesis 1), and, consequently, by more incentives favouring on-site nature conservation (see Hypothesis 2).
In general, our results do not confirm an unambiguous link between the degree of autonomy and the corresponding size of local tourism income. Comparing the autonomously operating indigenous groups and the pure salary-receiving communities that are employed by large agencies, both do in fact currently receive substantial benefits, particularly vis-à-vis their limited alternative sources of monetary income. Each of the relatively small communities receives an annual income of between US\$ 15000 and 50 000, which represents a significant rise in local purchasing power, in regard to the previous 'no tourism' situation.

Some illusions exist among NGOs and local indigenous groups about the ease of raising income through totally independent operations. This stems primarily from an underestimation of the costs, risks and difficulties related to the commercialisation of tourism products. In fact, it would seem much wiser for most villages to improve and specialise in local services, leaving the commercialisation and logistics part to the agencies, at least while accumulating more local experience.

Factors that determine the observed tourism income differences between communities are the degree of indigenous organisation and tourism specialisation, the appeal of the natural sites (including their present conservation status) and cultural attractions, and the quality of local services (including the adaptability to tourist demands). For instance, villages that due to past favourable access to transport and markets (or due to external pressure from migrant squatters and oil companies) have already embarked on a development path focussed on cattle and commercial crops, face a natural environment that has already deteriorated to a point where local attractions of flora and fauna are less competitive, compared to more virgin forest areas deeper in the Reserve. The specific local history of past natural resource management is thus an important precondition for the options to develop tourism on a significant scale.

Internal organisational capacity is another important precondition, especially for implementing (semi-) autonomous models of community- or village-based tourism. The presence of a community leader with crosscultural knowledge and a good understanding of the logistics of a local tourism operation has proved to be an invaluable asset for the community of Zábalo. At the same time, this is a special success factor that is not directly replicable in other villages.

In the transition path from higher income to socioeconomic change, it was shown that most of the observed tourism-induced changes are perceived as either positive or neutral. Only in one village (Puerto 
Bolívar) with very high visitor rates (and poor tourism planning), certain problems of highly skewed tourism income distribution and early 'acculturation' could be observed.

In terms of conservation, it was confirmed that tourism income tends to change local attitudes and behaviour, such as diminishing overexploitation, creating 'untouchable' zones and user quotas. The exact size of income is usually not decisive for this process; this type of local resource management adjustment could be observed in each of the three villages specialised on tourism (Zancudo, Zábalo, Puerto Bolívar). In the more independent case of Zábalo, the incentive for introducing self-regulation schemes was higher than in the other two cases, where external agents had a greater influence on this decision. Additionally, the mere fact that labour time is invested in tourism specialisation leaves less opportunity for hunting and other activities that may have been practised unsustainably in the past.

In the two villages where tourism appeared to be complementary (San Pablo, Playas), the circumstances are different. The proximity to markets and the introduction of cattle and commercial crops are land use dynamics that were too powerful to be reversed by the opportunities from tourism. Although labour time is invested in tourism, this is unlikely to result in much reduction or modification of other types of (environmentally degrading) activities. Moreover, the high degree of initial environmental degradation limits the tourist appeal, and thus the possibilities to specialise on tourism. This may indicate that the link between tourism income and local conservation practices is stronger in the early phases of a commercially oriented development process. Its opportunities tend to disappear when degradation impacts have become too strong.

Finally, at the level of national decision making, tourism income has until now helped to protect the Cuyabeno Reserve against important external threats, such as oil drilling and colonisation - a vital determinant for preserving its integrity.

The conclusions of this study lead to various suggestions in order to augment local participation, and thus strengthen both local incentives and the efficiency of tourist operations. ${ }^{70}$

1. Local nature guides: In situ observation of the operations reveal that locals tend to have knowledge and abilities in this field which are highly appreciated by the tourist, and which could be developed by further training, instead of relying exclusively on
Quito-based guides (biologists, etc.), as in the case of Transturi. For locals, the higher responsibility and salary than offered for assistant labour would be indeed be attractive.

2. Local food production: As shown in Table 7, there is almost no local production for tourist food consumption. The reason for this is the difficulty to match a limited, and often unreliable, local supply with a fluctuating tourist demand; tourist preferences, storage difficulties and hygienic requirements are mentioned as additional obstacles. However, there seems to be scope for a small-scale production of certain high value per hectare items, such as fruits and vegetables, which could complement local income without creating additional land use pressures.

3. Handicrafts and cultural services: The case of Zábalo illustrates that handicraft sales may constitute an important source of income, if embedded within a holistic cultural experience on the part of the tourist. In San Pablo, this was achieved by performing traditional dances and rituals. Depending on the willingness of local communities to 'revive' traditions for commercial purposes, this may be another source of complementary income.

4. General features: The options for augmenting local income by handicraft and food production, the training of local tourist guides and other available options, ${ }^{72}$ depend on the context of local possibilities and interests. A beneficial environment for the creation of local incentives exists when a long-term relationship between agency and community has been established, allowing for mutual processes of confidence building and learning. An omnipresent observation in this work is that the process of raising local responsibilities and income should be carried out step by step, in parallel with the gradual creation of local capacity and experience.

Even with the suggested gradual process, it should be noted that many of the induced changes necessarily come 'in packages'. Let us recall the three preconditions for ecotourism classification:

- minimal physical and social impact on the visited area;

- ecological education provided to the tourist; and

- significant economic participation by local resource managers.

In principle, each criterion should be satisfied independently. However, the experience of Cuyabeno shows that many changes are linked inevitably to each other, e.g., the rise in income goes along with changes in 
Table 8. Examples of potential conflicts between the goals of raising local tourism income and of minimising social and environmental impacts

\begin{tabular}{|c|c|c|}
\hline Higher Economic Participation & Possible Environmental Impact & Possible Social Impact \\
\hline \multirow[t]{2}{*}{ Higher food sales } & $\begin{array}{l}\text { Expansion of the local agricultural } \\
\text { frontier by deforestation }\end{array}$ & $\begin{array}{l}\text { Higher competition for local } \\
\text { production factors, esp. land }\end{array}$ \\
\hline & $\begin{array}{l}\text { Use of chemicals in production in order } \\
\text { to raise productivity }\end{array}$ & $\begin{array}{l}\text { Increasing labour costs, demand- } \\
\text { led wage inflation }\end{array}$ \\
\hline \multirow{2}{*}{$\begin{array}{l}\text { Higher local responsibility and labour } \\
\text { time invested in tourism }\end{array}$} & & $\begin{array}{l}\text { Cultural changes, abandon-ment of } \\
\text { traditional activities }\end{array}$ \\
\hline & & $\begin{array}{l}\text { New disequilibria in gender-specific } \\
\text { relations }\end{array}$ \\
\hline \multirow[t]{2}{*}{$\begin{array}{l}\text { Higher income transfers from tourist } \\
\text { agencies and tourists towards the local } \\
\text { economy }\end{array}$} & $\begin{array}{l}\text { Purchase of outboard motors, exotic } \\
\text { consumption goods, production of } \\
\text { garbage etc. }\end{array}$ & $\begin{array}{l}\text { Higher inequalities within the } \\
\text { community }\end{array}$ \\
\hline & & $\begin{array}{l}\text { Higher alcohol consumption, } \\
\text { features of 'acculturation' }\end{array}$ \\
\hline $\begin{array}{l}\text { Higher sales of handicrafts to the } \\
\text { tourist }\end{array}$ & $\begin{array}{l}\text { Danger of overexploitation of scarce } \\
\text { plant or animal species }\end{array}$ & $\begin{array}{l}\text { Promotion of an artificial and } \\
\text { commercialised concept of the } \\
\text { traditional culture }\end{array}$ \\
\hline
\end{tabular}

consumption patterns and with certain substitutions in productive activities. Potentially, this applies also to some of the recommendations that we have made, which must be designed to minimise negative side effects. ${ }^{73}$

There are a number of potential trade-offs between ecotourism criteria 1 and 3, i.e., between higher local income generation and the minimisation of social and environmental impacts (Table 8). It should be noted that Table 8 is an list of all possible conflicts - it does not mean that all of them must always apply in a deterministic way.

However, the purpose is to show that 'desirable' and 'undesirable' impacts cannot always be separated in the unambiguous manner suggested by the principal axioms of ecotourism, in the face of the complex socioeconomic and environmental changes that are brought about by tourism. Ultimately, it is first and foremost up to the specific community and its members to decide what type of changes they regard as beneficial and/or acceptable and, together with land use planners, how to design 'impact-minimising' scenarios and reconcile local concerns with the conservation objectives of a protected area.

\section{ENDNOTES}

${ }^{1}$ Field data was collected in Cuyabeno and Quito from January to April 1996. This work formed part of the author's 1993-96 assignment to the IUCN Forest Conservation Programme, based in the IUCN Regional Office for South America in Quito, financed by the Danish Agency for Development Assistance (Danida). A partner in the initiative to carry out research on this issue in Ecuador was the Quito-based tourism company Transturi/Cemecotur that is operating in Cuyabeno - a special thanks to Raúl García for his comments and for logistic support in the field. The present paper summarises issues and results from a previous and more comprehensive IUCN research report in Spanish, published in June 1996 (Wunder 1996). The author would like to thank Andrew Drumm, Albrecht Pfrommer, Joep Hendriks, Leida Buglass and Deborah Meadows Steketee for comments on earlier drafts. Kreg Lindberg and Tim Jessup acted as CIFOR's external reviewers of the paper.

${ }^{2}$ Although this may materialise in terms of higher donations to the natural area that was visited (the Galápagos islands are a prominent example), this impact should be seen as an external, rather than site-specific 
support, which will not be included in the following economic analysis.

${ }^{3}$ It may not be critical that nature tourism has a (minor) negative environmental impact in absolute terms, as long as this is negligible compared to a (more significant) effect of competing and forest-degrading land use options, such as logging, agriculture and cattle ranching. In principle, the same comparative approach should be applied to the evaluation of social impacts.

${ }^{4}$ Definitions focus on an 'environmental responsible' tourism (Ceballos-Lascuráin 1993) that provides 'direct benefits' to the nature conservation area and to 'the economic welfare of local residents' (Ziffer 1989) or, more generally, a 'nature tourism that promotes conservation and sustainable development' (Boo 1992).

${ }^{5}$ Consequently, some observers are talking about an across-the-board 'ecoterrorism' (Pleumarom 1995) - a term which seems equally indiscriminate.

${ }^{6}$ Note the implicit assumption here that the local distribution of tourism income is supposed to be sufficiently broad to allow all the relevant resourcedegrading actors to receive incentives in order to change current practices. Alternatively, these actors may be forced or induced to change practices by tourism-led resident interests, for instance through altered rules in the access to and use of natural resources.

${ }^{7}$ The travel cost method (TCM) represents a valuation of the potential 'willingness to pay' on behalf of tourists to a specific site which, however, is not currently matched by a cash flow. The calculated value may thus be of interest to a welfare-maximising land-use planner. However, because of various methodological problems, it is doubtful whether TCM values reflect an economic rent that can truly be captured by entrance fees, etc., in order to be transformed from economic value to financial incentive.

${ }^{8}$ Own calculations based on Groom et al. (1991: 403-9).

${ }^{9}$ In the terminology of economics, the primitive type of tourism has a higher local multiplier and backward linkage effect than the upmarket version.

${ }^{10}$ Unfortunately, the study lacks an analysis of aggregate local income flows (at the community or household levels) which would make it possible to determine the relative significance in the local economy.

${ }_{11}$ More recently, though, the GTZ-implemented PROFORS project has taken up ecotourism in Cuyabeno, and national environmental NGOs such as Fundación Natura and Ecociencia are initiating similar local activities.

${ }^{12}$ Arias Acosta (1994) claims the opposite in his economic valuation exercise, but his analysis suffers from a number of flaws, in particular the uncritical extrapolation of rather controversial forest product values from Iquitos, Peru to the Cuyabeno setting.
${ }^{13}$ In principle, environmentally friendly oil extraction techniques exist that avoid both the construction of penetration roads and pollution threats. Yet a combination of high extraction costs, lower oil prices on the world market and a lack of political will have meant that these techniques have not been employed on a wider scale in the Ecuadorian Amazon.

${ }^{14}$ Due to the impact of oil companies, squatters and overhunting, the Limoncocha area had gradually been degraded and lost much of its tourist value over the years.

${ }^{15}$ In Ecuador's system of protected areas, the category of 'Wildlife Reserve' respects preexisting human settlements and allows certain traditional productive activities to be carried out, as long as they are thought to be compatible with conservation purposes, according to regulations administered by INEFAN.

${ }^{16}$ In addition to these indigenous groups, mestizos originating from Quito and from neighbouring towns like Lago Agrio are also employed in Cuyabeno tourism operations. However, as these groups do not actually live inside the Reserve, they are excluded from the following analysis of local incomes.

${ }^{17}$ Ceballos-Lascuráin (1993) provides various aggregate estimates of village-based tourism income, but without specifying sources or subcomponents. The same is true for a later BMZ study (BMZ 1995a and BMZ 1995b) that basically relies on Ceballos' estimates. We will return to these earlier estimates for a comparison with results from the present study.

${ }^{18}$ The questionnaire that was used in Cuyabeno villages included basic questions about demographics, market integration, cash and subsistence production, and relation to the forest (access rules, benefits, forest clearing). Regarding ecotourism impacts, we asked questions about income flows and their seasonal structure, local tourist spending, local organisation, perceived economic and social changes, and income distribution.

${ }^{19}$ We used one sheet with questions about their spending and their appreciation of different tour elements.

${ }^{20}$ Recently, though, Transturi has replaced food deliveries by a flat monthly transfer of 1000000 sucres (\$US $1=2950$ sucres).

${ }^{21}$ The number of pre-1995 permanent Transturi employees has been cut by $75 \%$.

${ }^{22}$ According to field interviews in Zancudo.

${ }^{23}$ There is a scheme of both pooled tips among all inthe-field employees and personal tips that the tourists hand out directly to individuals.

${ }^{24}$ Occasional migration for wage labour in the cities and with oil companies, goods and services for the military, plus remittances from migrated family members are the most common but limited alternatives. 
${ }^{25}$ Transturi has also invested about US\$ 15000 in beds, transport infrastructure, etc..

${ }^{26}$ The vendors that choose to sell their products at the visitor centre have an obligation to wear the traditional Cofan costumes (which are not utilised on a daily basis in the village itself); if this rule is violated, they will be fined by the community.

${ }^{27}$ As mentioned above, we are interested in the local economic impact, so that external costs should be subtracted from gross turnover. In the following cases of motorised transport, this means that the cost of gasoline, oil (about 40\%) and motor depreciation (about $15 \%$ ) must be deducted, leaving $45 \%$ of gross turnover for the remuneration of labour and for net profits. These percentages, based on local interviews, differ slightly from the ones used in BMZ (1995a: 304), which may be due to a different category definition.

${ }^{28}$ Gross income minus all variable costs. This means that this figure also has to cover depreciation of the investments made by Transturi and by the Zábalo joint venture associates.

${ }^{29}$ Ceballos-Lascuráin (1993: 56) estimated income flows of US\$ 20,000-30,000/year.

${ }^{30}$ Buglass/PROBONA (1995:97) estimated an aggregate benefit of 45,000 US $\$$, but this is all attributed to Aguarico Trekking, without recognising the Flotelrelated income share.

31 Apparently, the following description is also partly representative of the type of tourism that is practised by Shuars, an ethnic group that was not studied in the present work.

${ }^{32}$ In addition, the area falls within the new concession area of the Occidental Oil Company, so future environmental pressures will probably be even more severe.

${ }^{33}$ Because of their Peruvian origin, the Secoyas maintain traditional links to this area. However, the Quichuas from Zancudo today claim exclusive access to this area, constituting a potential source of conflict.

${ }^{34}$ Although 'fixed' in principle, just as in the Transturi case, Etnotur has had to cut back somewhat on these payments during the tourism crisis that emerged in 1995 in response to the military conflict with Peru.

${ }^{35}$ Etnotur provided subsidised credit (and some training) for the motors, and now pays a fixed amount for each use; however, unlike other agencies, they do not need to worry about thefts of gasoline, bad maintenance, etc., because the owners have a clear incentive to operate efficiently.

36 There is additional transport using canoes without motors, for crossing rivers, minor trips, etc.

${ }^{37}$ Personal comments from various operators in Quito.
${ }^{38}$ Neotropic has built proper huts near the lakes; however, the other agencies are renting access to basic open bamboo-type constructions that provide the necessary shelter to put up tents or mosquito nets.

${ }^{39}$ Previously, Neotropic had employed Secoyas rather than Sionas, which created problems with the Sionas, as well as between Sionas and Secoyas. In spite of the goodwill demonstrated by this move, Neotropic is not satisfied with the current quality of the services provided by the Siona employees.

40 According to the yearly entrance statistics for the Cuyabeno lakes recorded by the INEFAN park authorities.

${ }^{41}$ This comparison also applies to the BMZ study (op. cit.) which mainly draws on Ceballos' results. Income for San Pablo was estimated neither by Ceballos nor by the BMZ authors. The three years of time lag in the collection of our data provide no explanation of the varying estimates, as overall tourism income is likely to have declined during this period.

${ }^{42}$ Of course, the associated aspect of specialisation is the creation of dependence: in the absence of tourism, most residents in the remote Cuyabeno villages did not have alternative monetary income sources in the past, nor would they have if tourism was to decline in the future.

${ }^{43}$ In contrast, in subsistence-oriented villages with very low cash income, it is more usual to use non-monetary systems of (individual or communal) reciprocal labour exchange (cambiamano or minga).

${ }^{44}$ Calculated as 500000 sucres a month divided by 26 monthly working days.

${ }^{45}$ However, this is only true for the 12 permanent employees of Transturi; the 2 day-to-day employees receive less than the local jornal (6500 sucres/day). However, day employment may be an entry to permanent employment, with a good probability to gain a much higher salary in the future.

${ }^{46}$ The lower jornal value compared to that in Playas mainly reflects a lower cost of living in San Pablo, its closeness to the road and lower transport costs of food items, etc. which make the traditional consumption basket cheaper.

${ }^{47}$ See Table 5 for the data used in this calculation.

${ }^{48}$ One reason for not treating this question is profit measurability: many agencies have invested significant sums of money in commercialisation and infrastructure during previous years. BMZ (1995a: 321) estimates that only $15 \%$ of gross tourism income stays in the local economy, but data on net profits - a more relevant measure - are not sufficiently transparent. Another reason for omission is relevance: in spite of the 
experience of Zancudo (see discussion above), we believe that for local conservation purposes, the size of incomes relative to local economic alternatives is generally more important than its relationship to the Quito-based agency's profit.

${ }^{49}$ Note that the optimum solution is not necessarily to transfer responsibility to the community as such, but rather to those individuals that express interest and ability to participate actively in the operation.

${ }^{50}$ A frequent problem on Transturi's Flotel Orellana is, e.g., the theft of foodstuff and gasoline by the employees.

${ }^{51}$ This refers, e.g., to the higher quality of nature guides in the autonomous case of Zábalo, compared to the salary-based employment in Puerto Bolívar.

${ }^{52}$ As mentioned, several agencies have chosen to transfer outboard motors to local community members, in order to ensure appropriate maintenance and a higher reliability of river transport.

${ }^{53}$ Obviously, another factor of differentiation is the complexity of the operation. It can be argued that, in the case of the complex logistics of Transturi's Flotel operation, it is more risky to rely on the local personnel's own organisational skills than for a smaller agency with a more flexible operation.

${ }^{54}$ This is in line with the classic trinity view of the concept of sustainability encompassing economic, social and environmental dimensions.

${ }^{55}$ In the literature on development and income distribution, it is suggested that inequality tends to rise in the early stages of development, only to decline later - a phenomenon referred to as 'Kuznets' inverted Ucurve'.

${ }^{56}$ As noted above, handicraft sales have a large economic impact, and salary payments are higher than in the rest of Cuyabeno - both factors working towards a more equitable income distribution.

${ }^{57}$ For example, in Puerto Bolívar, where Siona customs are increasingly replaced by Quichua elements (music, etc) - personal comment, A. Drumm).

${ }^{58}$ In the case of Zábalo, tourism was a raison d'être in the decision to move to a new location; in Zancudo, basically no other cash income sources exist.

${ }^{59}$ Alcohol is a problem only in Puerto Bolívar, where a group of youngsters seems to have been adversely affected by the ease of acquiring tourism income from the large yearly influx of tourists, showing symptoms of 'acculturation'.

${ }^{60}$ See Stankey et al. (1985) for a description of LAC.
${ }^{61}$ With reference to the ongoing studies by Antje Müllner and Albrecht Pfrommer from the University of Würzburg, Germany.

${ }^{62}$ Because hunting often represents the exclusive source of protein, many indigenous groups display a rather high per capita consumption of game meat. Traditional hunting practices may be sustainable in areas of extremely low population density, where settlements can be shifted cyclically. However, in Cuyabeno this is no longer a fully viable option.

${ }^{63}$ A step in the same direction has been Transturi's attempt to introduce African sheep into the community - raising stock would provide a sustainable protein alternative. Apparently, rather than augmenting the stock of sheep, the people from Zancudo have chosen to sacrifice the introduced sheep for their immediate alimentary satisfaction.

${ }^{64}$ Personal comment by researchers Antje Müllner and Albrecht Pfrommer who currently reside in the Cuyabeno lakes area.

${ }^{65}$ For example, the villagers mention that hunting has been abandoned in San Pablo - but only during the days when the tourists are in the village!

${ }^{66}$ Of course, this is not meant to be a carte blanche to ignore tourism impacts, but rather a call for realism and adequate balance in the discussion about current land use dynamics in Ecuador.

${ }^{67}$ Including 'multiplier effects' and derived tourist expenses in Quito and other parts of Ecuador, the contribution of Cuyabeno tourism to the national economy is much higher than the turnover by tourist agencies. In the case of Aguarico Trekking, it has been estimated that the full benefit to Ecuador amounts to US\$ $500000 / y r$.

${ }^{68}$ Personal comment, Randy Borman, community leader of Zábalo, 8 January 1996.

${ }^{69}$ Personal comment, Andrew Drumm, Quito, 13 May 1996.

${ }^{70}$ For a more elaborate set of recommendations, see Wunder (1996: 82-6).

${ }^{71}$ The PROFORS project has taken the first steps in this field, with two courses for nature guides in Puerto Bolívar, in 1994 and 1995.

${ }^{72}$ This includes local operation of motorised canoes, hut accommodation, etc.

${ }^{73}$ For instance, in the production of certain handicrafts, feathers or threatened plant species have been used in the past, thus causing undesirable environmental impacts. 


\section{LITERATURE CITED}

Arias Acosta, J. 1994 Elements for calculating the value of biological diversity losses: the case of oil exploration at Cuyabeno Reserve in the Ecuadorian Amazon region. In: Munasinghe, M. and McNeely, J. (eds.) Protected area economics and policy - linking conservation and sustainable development, 205-219. World Bank/IUCN, Washington, DC.

BMZ 1995a Ökoturismus als Instrument des Naturschutzes? Möglichkeiten zur Erhöhung der Attraktivität von Naturschutzvorhaben, Arbeitsgruppe Ökoturismus, Forschungsberichte des Bundesministerium für Wirtschaftliche Zusammenarbeit und Entwicklung, Band 116. Weltforum Verlag, München, Köln, Germany and London, UK (full study).

BMZ 1995b Ökoturismus als Instrument des Naturschutzes? Möglichkeiten zur Erhöhung der Attraktivität von Naturschutzvorhaben, Arbeitsgruppe Ökoturismus. Weltforum Verlag, Köln, Germany (resume and recommendations).

Boo, E. 1992 The ecotourism boom, planning for development and management. WHN Technical Papers Series, Paper \# 2. World Wildlife Fund, Washington, DC.

Buglass, L. and PROBONA 1995 Ecoturismo en el Ecuador, trayectorias y desafíos. Programa de Bosques Nativos (PROBONA), DDA/INTERCOOPERATION/UICN, Quito, Ecuador.

Calvopiña, J. and Calvopiña, L. 1993 Elementos para el manejo del ecoturismo en la Reserva Cuyabeno. Study for PROFORS (Programa Forestal Sucumbíos), Cooperación Ecuador-Alemania, Quito, Ecuador.

Ceballos-Lascuráin, H. 1991 Tourism, ecotourism and protected areas. CNPPA 35th Working Session, UICN, Santo Domingo, República Dominicana.

Ceballos-Lascuráin, H. 1993 Promoción del ecoturismo dentro de la Reserva de Producción Faunística Cuyabeno. Study for PROFORS (Programa Forestal Sucumbíos), Cooperación Ecuador-Alemania, Quito, Ecuador.

CEMOCOTUR/Transturi 1994 Convenio de participación y cooperación entre la comunidad de Zancudococha y CEMECOTUR (before Transturi), 13 May. Quito, Ecuador.

Drumm, A. 1991 Integrated impact assessment of nature tourism in Ecuador's Amazon region. Study for FEPROTUR-NATURALEZA, Quito, Ecuador.

Groom, M.J. et al. 1991 Tourism as a sustained use of wildlife: a case study of Madre de Dios, Southeastern Peru. In: Robinson, J.G. and Redford, K.H. (eds.) Neotropical wildlife use and conservation, 393-412. University of Chicago Press, Chicago, Ill.

Healy, R.G. 1988 Economic considerations in nature-oriented tourism: the case of tropical forest tourism. FPEI Working Paper No. 39. Southeastern Center for Forest Economic Research (SCFER), Research Triangle Park, NC.

Healy, R.G. 1992 Ecotourism, handicrafts and the management of protected areas in developing countries, draft., School for the Environment, Center for Tropical Conservation, Duke University, Durham, NC.

Laarman, J.G. and Durst, P.B. 1991 Nature tourism as a tool for economic development and conservation of natural resources. College of Forest Resources, North Carolina State University, Raleigh, NC.

Lindberg, K. and Enríquez, J. 1994 An analysis of ecotourism's economic contribution to conservation in Belize, volume 2: Comprehensive report. World Wildlife Fund and Ministry of Tourism and the Environment (Belize), Washington, DC.

Paz y Miño, G. 1990 Evaluación sobre el estado de manejo de la Reserva de Producción Faunística Cuyabeno (Amazonía del Ecuador) y medidas emergentes que podrían tomarse para su administración adecuada, Quito, Ecuador.

Pleumarom, A. 1995 Environmental Justice Networker, No.6, Winter. Third World Networking Features.

Stankey, G.H., Cole, D.N., Lucas, R.C., Petersen, M.E. and Frissell, S.S. 1985. The limits of acceptable change (LAC) system for wilderness planning. General Technical Report INT-176, US Forest Service, US Dept. of Agriculture, Ogden, Ut.

Tobias, D. and Mendelsohn, R. 1991 Valuing ecotourism in a tropical rain forest reserve. Ambio 20: 91-3.

Ulloa V.R. 1994 Evaluación de impactos ambientales, Flotel Francisco de Orellana, Campamentos de Imuya e Iripari. Study for CEMECOTUR/Metropolitan Touring, Quito, Ecuador. 
Whelan, T. (ed.) 1991 Nature tourism, managing for the environment. Island Press, Washington, DC.

Wunder, S. 1996 Ecoturismo, ingresos locales y conservación. El caso de Cuyabeno, Ecuador. IUCN and Abya Yala, Quito, Ecuador.

Ziffer, K.A. 1989 Ecotourism: the uneasy alliance. Conservation International Working Papers on Ecotourism. Ernst and Young for CI, Washington, DC. 